\title{
A retórica musical e o choro
}

\author{
MÁRIO SÈVE WANDERLEY LOPES*
}

\begin{abstract}
RESUMO: Este artigo tem a intenção de apontar caminhos para a análise do choro, a partir de um referencial teórico da retórica musical (CANO, 2011; BARTEL, 1997; RATNER, 1980). O texto associa alguns conceitos da retórica musical com procedimentos usados na música que surgiu no Brasil no século XIX a partir das danças que chegaram da Europa. São apresentadas as supostas origens e significados do termo choro (TINHORÃO, 1991; ARAGÃO, 2013; CAZES, 2010). São descritos os contextos do surgimento da retórica, da música poética e do desenvolvimento do sistema retórico-musical, a partir de pesquisas musicológicas em tratados barrocos (REBOUL, 2004; CANO, 2011; BUELOW, 1980). São expostas aplicações da chamada "teoria das tópicas" fora do âmbito da música barroca incluindo-se aí o classicismo europeu (RATNER, 1980), diferentes estilos musicais brasileiros (PIEDADE, 2007) e o choro, especialmente. Por fim, são relacionados alguns conceitos e usos de figuras retóricas para propor um paralelo possivel entre exemplos musicais extraídos de obras barrocas e de peças do repertorio de choros.
\end{abstract}

Palavras-chave: Retórica musical, tópicas, figuras retóricas, choro, música brasileira.

\section{The Musical Rhetoric And The Choro}

\begin{abstract}
This article aims to point out ways to analyze the choro, based on a theoretical reference of musical rhetoric (CANO, 2011; BARTEL, 1997; RATNER, 1980). The text associates some concepts of the musical rhetoric with procedures used in the music that emerged in Brazil in the nineteenth century from the European dances. The supposed origins and meanings of the term choro are presented (TINHORÃO, 1991; ARAGÃO, 2013; CAZES, 2010). The contexts of the emergence of rhetoric, poetic music and the development of the rhetorical-musical system are described, based on musicological researches in baroque treatises (REBOUL, 2004; CANO, 2011; BUELOW, 1980). Applications of so-called theory of the topics are exposed outside the scope of Baroque music - including the European classicism (RATNER, 1980), different Brazilian musical styles (PIEDADE, 2007) and the choro. Finally, some rhetorical figures concepts are used to propose a possible parallel between musical examples extracted from baroque works and choro pieces.
\end{abstract}

Keywords: musical rhetoric, topics, rhetorical figures, choro, Brazilian music.

\footnotetext{
* Mário Sève Wanderley Lopes é Doutorando e mestre em música (UNIRIO), com artigos publicados em congressos (ANPPOM), simpósios (Simpósio Nacional Villa-Lobos e SIMPOM) e revistas (Debates n. 14 e 17). Escreveu os livros Vocabulário do Choro, Songbook Choro e Choro Duetos. É saxofonista, flautista, compositor, arranjador e integrante dos quintetos Nó em Pingo D’Água, Aquarela Carioca e do grupo de Paulinho da Viola. Idealizou e dirigiu o festival Riochoro e diversas séries nos CCBBs. Gravou os cds Bach \& Pixinguinha, Choros, por que sax?, Pixinguinha + Benedito, Casa de todo mundo e Canción necesaria, e o dvd Samba errante. Tem obras gravadas por Monica Salmaso, Roberta Sá, Carol Saboya, Suzie Franco, Mauro Aguiar, Berkeley Choro Ensemble e Cecilia Stanzione. Atuou como instrumentista com Ney Matogrosso, Alceu Valença, Guinga, Zeca Pagodinho etc. E-mail: marioseve@gmail.com
} 


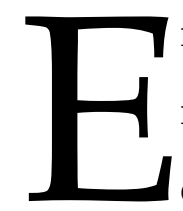
mbora a palavra "choro" só tenha se fixado como nome de um gênero musical a partir das primeiras décadas do século XX, por volta de 1870 ela já era usada para designar um estilo de se tocar composições instrumentais brasileiras baseadas em danças originárias da Europa, em especial a polca. (TINHORÃO, 1991, p. 103). Tais práticas musicais realizavam-se por meio de uma instrumentação à base de sopros (como flautas e clarinetes nos solos e oficleides nos contrapontos) e cordas (com cavaquinhos e violões no acompanhamento rítmicoharmônico e nos contrapontos). Posteriormente, adicionou-se a percussão, especialmente o pandeiro, estabelecendo uma formação que, mesmo com pequenas diferenças, tem permanecido até os dias de hoje.

De uma maneira geral, a literatura sobre o gênero tem tentado descrever seu estilo lançando mão de expressões do tipo "chorado", "exacerbadamente sentimental", "amaciando", "amolecia", "um jeito brasileiro de tocar" etc. Ao não se submeter apenas à notação, a música dos chorões tem sido construída sobre códigos alternativos, alguns destes criados a partir do uso de palavras que representam afetos e procedimentos de seu coletivo. Poderíamos perceber em imagens e sensações contidas nos termos "dolente", "cochicho", "enigmático", "murmurando", "delicado", "ginga", "gostosinho", entre inúmeros outros, algumas sugestões para se compreender as criações musicais do repertório chorístico. São palavras que acabam chegando aos próprios títulos das peças.

O enfoque analítico aqui proposto, associado a ensinamentos da retórica, parte de estudos que já nortearam, em antigos tratados, procedimentos composicionais para a música barroca (CANO, 2011; BARTEL, 1997; BUELOW, 1980; HARNONCOURT, 1998; QUANTZ, 2001), durante os princípios do tonalismo. Esse enfoque relaciona-se diretamente ao entendimento de discursos e sentidos musicais - mesmo em se tratando de peças instrumentais, como veremos no decorrer deste artigo. Nesse contexto, frases, repetições, contrapontos, formas, intervalos, consonâncias, dissonâncias etc. são procedimentos musicais que se relacionam com aquilo que se pretende comunicar ao ouvinte. Monteverdi, Vivaldi, Bach, e praticamente a totalidade dos compositores barrocos, teriam gerado suas obras assim, influenciando Mozart, Haydn, Beethoven e tantos outros autores do 
classicismo ou, até mesmo, do próprio romantismo - cuja música, nas palavras de Mário de Andrade (1942, p. 108), também procurou sistematizar "processos construtivos e interpretativos de intenção sentimental". Esses estilos, por sua vez, influenciaram - formal, harmônica e fraseologicamente - diversas danças europeias que aportaram nas Américas do século XIX, como a valsa, a polca e a schottisch.

\section{O termo choro}

Há diferentes versões para a origem da palavra choro. Pedro Aragão (2013, p. 34) expõe cinco possíveis hipóteses: a) para Câmara Cascudo ela seria uma corruptela de "xolo" (baile de negros); b) para Mozart de Araújo viria da "expressão dolente, chorosa" da música executada; c) para Ary Vasconcelos seria derivada de "choromeleiros" (corporação musical, no período colonial); d) para Baptista Siqueira, viria do emprego equivocado da expressão latina "chorus", em um catálogo da Casa Edison; e e) para Curt Lange seria uma possível incorporação do termo alemão chore.

Corroborando de uma maneira ou de outra estão ainda: a) a de José Ramos Tinhorão (1991, p. 103), que choro viria de uma maneira de tocar passagens em sons graves executadas pelo violão, conferindo "impressão de melancolia"; e b) a de Henrique Cazes (2010, p. 17), que decorreria da "maneira chorosa de frasear", gerando o termo chorão para o músico que "amolecia" as polcas. O próprio Aragão comenta que a bibliografia clássica destaca que o choro nasceu de um jeito brasileiro (este ligado à sincopação, tida como africana) de tocar danças europeias. Assim como as versões de Tinhorão, Cazes e Araújo, ele associa o termo choro a questões interpretativas peculiares.

Muniz Sodré (2007, p. 31) diz que se dava o nome de "lundu-chorado" a uma dança em que se acentuavam "o meneio dos quadris, do jogo do corpo, o movimento sensual das mãos." Ao supormos que a fusão da polca com o lundu (polca-lundu) se encontra na gênese da criação do choro e do maxixe, teríamos então outra hipótese para a origem e o significado da palavra choro: ela traria a conotação de sincopação contida no sufixo "chorado" do lundu. 
No livro de Alexandre Gonçalves Pinto (1936) ${ }^{1}$, choro é usado para designar um agrupamento musical, uma peça ou um gênero musical e, ainda, a festa ou o lugar físico onde se praticava essa música. (ARAGÃO, 2013, p. 82). A palavra, que se estabilizou nesses significados, hoje se liga também a um estilo de tocar e compor, em um vocabulário fraseológico próprio.

Diversas questões se entrecruzam nas hipóteses sobre as origens e usos do termo choro. Como peças instrumentais, mesmo que eventualmente apresentem títulos descritivos, os choros comportam ainda outros enigmas, estes relacionados ao entendimento de seus discursos musicais. O mais básico e geral vem da mescla de padrões do tonalismo europeu com organizações rítmicas de origem africana. No sentido de se investigar outros significados contidos nas obras dos chorões, escolhi como ponto de partida o estudo de uma velha ferramenta de análise e composição musical, usada em grande escala na Europa do período barroco.

\section{A retórica e a música poética}

O que ficou conhecido no período barroco pelo nome de musica poetica tratava-se de uma nova teoria, a partir da qual se pudesse discutir processos musicais. Usando o motete In me transierunt, de Orlando di Lassus, Burmeister - em seu tratado Musica poetica, de 1606 - realizou a primeira "análise musical", estabelecendo a definição pioneira desta expressão.

Análise de uma composição é a determinação de seu particular modo e suas particulares espécies de contraponto, e dos afetos dos períodos... análise consiste em cinco partes: 1 . Determinação do modo; 2. Espécie de tonalidade; 3. De contraponto; 4. Considerações de qualidade; 5. Compreensão dos afetos ou períodos da composição. (BENT, apud CANO, 2011, p. 44).

Esse conceito era, em grande parte, fundamentado por uma disciplina relacionada ao estudo da correção, da eloquência e da persuasão na produção de discursos verbais: a retórica.

A retórica surgiu por volta de 485 a.C. em Siracusa, na Sicília. (REBOUL,

\footnotetext{
${ }^{1}$ Escrito pelo carteiro e músico amador de alcunha "o Animal", o livro O choro: reminiscências dos chorões antigos contém, em verbetes, o perfil de instrumentistas, compositores, cantores etc. ligados às práticas musicais na Cidade do Rio de Janeiro entre 1870 e 1930. (ARAGÃO, 2013, p. 14-20).
} 
2004; CANO, 2011; LEMOS, 2015). Os governantes Hierón e Gelón haviam decretado uma série de desapropriações afim de distribuir bens e terras a seus mercenários. Esses tiranos foram depostos em 466 a.C. por um movimento democrático empenhado em devolver direitos de propriedade a seus antigos donos. Mas como seria possível fazê-lo, se o que havia então eram conflitos internos e desordem? A solução foi a instauração de um júri popular ao qual cidadãos poderiam solicitar tais restituições por meio de discursos, já que não havia como dispor de documentos ou testemunhas oficiais. Despontaram, assim, oradores profissionais especializados na arte do uso da palavra.

Estão entre os primeiros principais autores retóricos: Aristóteles (384-322 a.C.), considerado o grande teorizador, Cícero (106-43 a.C.), o grande orador - para quem um discurso deveria agradar (delectare), instruir (docere) e comover (movere) o ouvinte -, e Quintiliano (35-aprox. 100 d.C), o grande pedagogo - que definia a retórica como “a arte do bem dizer" (CANO, 2011, p. 30).

Esses pensadores elaboraram, com algumas diferenças, um "sistema retórico" com as fases preparatórias para um discurso. Tais fases foram classificadas como: inventio (invenção), dispositio (disposição), elocutio (elocução), memoria (memória) e pronuntiatio ou actio (ação). A inventio corresponde à criação das ideias e dos argumentos do discurso. Ela procura recorrer a uma reserva coletiva de informações e convenções - as "tópicas" - para apoio de uma tese, dispondo cada ideia, cada argumento, em um $\operatorname{lugar}^{2}$ (locus) na mente do orador. A dispositio corresponde à distribuição e a ordenação das ideias e dos argumentos no decorrer do discurso, em um plano estrutural que se desenvolve em momentos distintos introdução, desenvolvimento e conclusão. A elocutio - termo que se associa à forma de expressão - corresponde à definição de um estilo para o discurso, com o objetivo de mover os afetos dos ouvintes, e diz respeito mais à escrita do discurso do que à palavra oral. Nesta parte, encontram-se os termos e as frases apropriadas, adequando a linguagem a ser usada - são escolhidas, ou criadas, as "figuras retóricas" (como a

\footnotetext{
2 Em épocas em que os suportes da escrita eram poucos, a memória exercia papel fundamental. O método mais comum de memorização consistia em construir mentalmente uma arquitetura, um espaço, e associar cada ideia a um objeto ou uma imagem. Ainda encontramos vestígios dessa técnica quando enumeramos ideias em uma fala - "em primeiro lugar..." , "em segundo lugar..." e assim por diante. (LEMOS, 2015).
} 
metáfora, a alegoria, a metonímia, a comparação etc.). A memoria corresponde à memorização do discurso, e a pronuntiatio à sua encenação, com atenção à dicção, ao ritmo e à altura da fala, ao gestual etc.

Atingindo seu apogeu na antiguidade grega e latina, a retórica foi na Idade Média uma das disciplinas do trivium - ao lado da gramática e da lógica (ou dialética) - e pertenceu, junto às disciplinas do quadrivium - a aritmética, a geometria, a música e a astronomia — , a uma das sete artes liberais ministradas no ensino universitário da época. (HOUAISS, 2001). Por transitar entre o quadrivium e o trivium (este, pela retórica), a música ganhou grande riqueza simbólica.

$\mathrm{Na}$ Europa dos séculos XVI, XVII e XVIII, a retórica teve um papel importante na vida social, cultural, educativa e religiosa. Cientistas, filósofos, escritores, sacerdotes e artistas buscavam lançar mão dos atributos e técnicas dos oradores com o objetivo de comover e convencer seus ouvintes, leitores e apreciadores. No campo das artes, a poética ${ }^{3}$, sistematizada em tratados com instruções e conhecimentos dos princípios da criação, assimilou termos e princípios da construção do discurso falado. De 1599 a 1791 - pelas mãos de autores como Joachim Burmeister, Athanasius Kircher, Johann Mattheson, entre outros - foram escritos os tratados que formaram "o grande corpus" de textos de retórica musical do Barroco (CANO, 2011, p. 35), desenvolvendo uma teorização poética própria.

A partir do Renascimento, intensificou-se o interesse pelas antigas culturas clássicas. Do fato do drama grego ter sido cantado, e não falado, surgiu a ideia de fazer-se da palavra, do diálogo, o fundamento da música (HARNONCOURT, 1998, p. 165-6), que deveria então apresentar conteúdo dramático (argumento, conflito, persuasão etc.). Conhecedor dos filósofos clássicos, Claudio Monteverdi (1567-1643), grande compositor de óperas e madrigais, sabia como procurar uma expressão musical para cada emoção humana. (HARNONCOURT, 1998, p. 168). O músico italiano, ao compor para Combatimento de Tancredo e Clorinda, de 1624, foi pesquisar como exprimir musicalmente a cólera, a agitação da alma. Recorrendo a Platão, conseguiu retratar esse sentimento no uso de tempos rápidos e notas repetidas,

\footnotetext{
${ }^{3} \mathrm{O}$ termo "poética" (do grego "criar") se refere à teorização, normatização, sistematização e invenção de instruções, conhecimentos e recursos técnicos com os quais conta o artista durante o processo de criação. (CANO, 2011, p. 43).
} 
chamando esta possibilidade de stile concitato. As notas repetidas passaram a ser empregadas como um meio de expressão e o concitato se tornou um procedimento artístico corrente (HARNONCOURT, 1998, p. 169), encontrado posteriormente em obras de Handel e Mozart, por exemplo. Aos instrumentistas da época, para os quais era incômoda a situação de executar várias notas repetidas, foi necessário que se explicasse esse seu "significado extra musical." Monteverdi tornou-se pioneiro em integrar o gesto à composição, segundo o maestro Nikolaus Harnoncourt (1998).

Aprendida nas escolas e universidades, e pertencente à cultura geral europeia, a retórica fez com que os músicos do século XVII, e parte do século XVIII, tomassem consciência da necessidade de estarem mergulhados em determinados sentimentos para poder transmiti-los. Músicos e ouvintes da época barroca só tocavam e escutavam a música mais moderna, o que fazia com que compreendessem bem as nuances da linguagem musical. (HARNONCOURT, 1998, p. 155). Havia, nesse ambiente, um repertório de "figuras retórico-musicais" - familiar aos compositores e a todo ouvinte culto - que foi incorporado até mesmo ao vocabulário da música instrumental.

Estudioso de Quintiliano, J. S. Bach construiu uma vasta obra - vocal e instrumental - fundamentada em regras das teorias clássicas da retórica e apoiada nesse repertório de figuras. Elas poderiam aparecer, por exemplo, na forma de "citação" (com uma significação simbólica encoberta), ao integrar motivos conhecidos de obras vocais às obras instrumentais. (HARNONCOURT, 1998, p. 154).

Para Harnoncourt, a relação entre músicos, ouvintes e retórica em torno de obras no período barroco assemelha-se, de muitas maneiras, a situações encontradas em diversas práticas da música popular de hoje, que costumam ter muitos dos seus significados transmitidos a partir de códigos compartilhados entre executantes e receptores.

na música popular encontram-se vários aspectos da antiga compreensão musical: a unidade poesia-canto, unidade ouvinte-artista e a unidade música-tempo; a música popular nunca tem mais de uns cinco ou dez anos, portanto, é parte integrante do presente. Talvez com a ajuda da música popular possamos ter uma ideia do que a música antigamente representava na vida das pessoas; de qualquer forma, em seu domínio, a pesar de restrito, a música popular é atualmente uma parte essencial da vida. (HARNONCOURT, 1988, p. 25). 
Os valores retóricos começaram a ser questionados a partir do século XVIII, no Iluminismo, restando como um dos seus últimos redutos a arte. No século XIX, ela passou a reduzir as qualidades retóricas (delectare, docere et movere) apenas a delectare, ao gozo da obra por ela mesma - um traço que, segundo Cano (2011, p. 42), encontra-se refletido nas exaustivas repetições do mesmo repertório europeu do século XIX por músicos virtuosos descompromissados em transmitir as propostas originais das obras.

No século $X X$, assim como a linguística (através da semiologia, do formalismo e do estruturalismo), a música (através da semiótica musical e da musicologia cognitiva) retomou o estudo da retórica, que voltou a ser ferramenta usada para análises de formas discursivas, verbais ou não.

\section{Os afetos e suas representações musicais no estilo barroco}

Embora desde a Grécia antiga já se registrassem ideias e reflexões sobre o vínculo da música a "estados emocionais", foi na era barroca que aconteceram as mais refinadas e complexas teorizações sobre o fenômeno. O amor, a tristeza, a cólera, a alegria, a dúvida, entre outros sentimentos, eram reconhecidos como "afetos" ou "paixões da alma." Na música, mesmo que uma verdadeira e definitiva teoria dos afetos não tenha sido constituída (PIEDADE; FALQUEIRO, 2007, p. 2), estados emocionais idealizados eram simbolizados em figurações e ocupavam lugar nos princípios composicionais da época, inclusive em obras instrumentais. George J. Buelow, nos fala de um processo de composição musical no estilo barroco:

O compositor barroco planejava o conteúdo afetivo de cada obra, ou seção ou movimento de uma obra, com todas as suas ferramentas artísticas, e esperava que a resposta de sua audiência fosse baseada em uma compreensão igualmente racional do significado de sua música. Todos os elementos da música - escalas, ritmo, estrutura harmônica, tonalidade, alcance melódico, formas, cor instrumental e assim por diante - eram interpretados afetivamente. Os estilos, as formas $\mathrm{e}$ as técnicas composicionais da música barroca eram, portanto, sempre o resultado deste conceito dos "afetos" (BUELOW, 1980).

As primeiras teorias do funcionamento dos afetos na música surgiram a 
partir de estudos gerais de diversos filósofos, como Ética, de Spinoza (1632-1677), e As paixões da alma, última obra escrita por René Descartes (1596-1650) e de grande influência sobre as artes - havia a crença de que ele havia descoberto uma explicação científica racional da natureza fisiológica das paixões e da natureza objetiva da emoção (DESCARTES, 1999). Descartes relacionava as paixões da alma (para ele, ligada à totalidade do corpo), ao fluxo do que chamava de "espíritos animais"

Os espíritos animais - "assim como os elementos da chama que sai de uma tocha, que não se detém em lugar nenhum" (DESCARTES, 1999, p. 111) seriam compostos de substâncias muito tênues do sangue que se movimentam pelo corpo dotados da capacidade de atingir o cérebro em suas partes mais profundas na região da glândula pineal, "parte do corpo em que a alma exerce diretamente suas funções" (DESCARTES, 1999, p. 124). O cérebro, ao receber estímulos, passa a provocar novos movimentos dos espíritos, que vão se concentrar em determinados órgãos do corpo, a depender do caráter da paixão. Tais agitações e concentrações seriam responsáveis por diferentes estados afetivos e diferentes reações corporais. Para Descartes (1999, p.106), “aquilo que nela [alma] é uma paixão em geral nele [corpo] é uma ação."

Seguindo o princípio da imitação analógica, a música do período barroco procurava associar seus elementos - desenhos melódicos, ritmos, estruturas harmônicas, tempos, tonalidades, formas, estilos, figuras retórico-musicais etc. - às sensações e aos movimentos corporais resultantes das paixões da alma para criar uma representação musical dos afetos. Supunha-se, por exemplo, que a tendência dos sons consonantes era estimular o fluxo dos espíritos animais, enquanto os dissonantes o refluxo - como no caso dos estados de cólera. Para Mattheson, a "alegria", sendo uma expansão dos espíritos, pediria intervalos melódicos extensos, enquanto a "tristeza", uma contração, intervalos estreitos; a "esperança", sendo uma elevação dos espíritos, pediria linhas melódicas ascendentes, enquanto a "desesperação", um decaimento, a dissonância e a aspereza. Para Descartes, os tempos musicais lentos estariam associados à languidez, à aflição, ao temor e à arrogância, enquanto os rápidos à leveza e à alegria. 
Johann Joachim Quantz (1697-1773) dizia que, para identificar-se o afeto dominante em uma peça, seria necessário analisar os seguintes elementos musicais:

1. se o modo é maior ou menor. Geralmente, um modo maior é usado para a expressão do que é alegre, ousado, sério e sublime, e um menor para a expressão do que é lisonjeiro, melancólico e terno. (...) 2. se os intervalos entre as notas são grandes ou pequenos e se as notas devem estar ligadas ou articuladas. O elogio, a melancolia e a ternura são expressos por intervalos próximos e ligados, enquanto a alegria e a seriedade são exprimidas por notas curtas articuladas, por saltos distantes, assim como por figuras pontuadas regularmente após a segunda nota. Notas pontuadas e sustentadas expressam o sério e o patético; notas longas, como semibreves ou mínimas, mescladas a notas curtas expressam o majestoso e o sublime. 3. As paixões podem ser percebidas a partir das dissonâncias. (...) 4. A quarta indicação do sentimento dominante é a palavra encontrada no início de cada peça, como Allegro, Allegro non tanto, -assai, -di molto, -moderato, Presto, Alegretto, Andante, Andantino, Arioso, Cantabile, Spirituoso, Affetuoso, Grave, Adagio, Adagio assai, Lento, Mesto etc. (QUANTZ, 2001, p. 125-6).

O item 1 acima está ilustrado pelo quadro com tonalidades e afetos que Cano (2011, p. 64) constrói em Música y retórica en el barroco a partir de tratados de Charpentier, Mattheson e Rameau, embora ele mesmo lembre que "nenhuma tonalidade pode ser tão triste ou feliz em si mesma de tal forma que também não possa representar um sentimento oposto." (MATTHESON apud CANO, 2011, p. 63).

Harnoncourt (1988, p. 181-2) diz que palavras como allegro, largo, presto e outras (como as citadas por Quantz no item 4) eram usadas por compositores dos séculos XVII e XVIII de acordo com o sentido que tinham no idioma italiano. Elas deveriam ser entendidas mais como uma indicação de caráter do que de tempo musical. Um allegro (que significa alegre) teria seu andamento ajustado - mais ou menos acelerado - para uma alegria decorrente do contexto da peça. Mattheson, segundo Cano (2011, p. 65-6), associava indicações de tempo a determinadas paixões - adagio a tristeza, lento a alivio, andante a esperança, affetuoso a amor e presto a desejo.

O teórico barroco também analisou afetos em diversas danças, relacionando menuet a alegria moderada, gavotta a alegria festiva, marche a heroísmo e valentia, rondeau a convicção, sarabande a ambição, courante a doce esperança, allemande a felicidade, bourrée, chaconne e passecaille a satisfação. Harnoncourt lembra que Vivaldi notou verbalmente indicações retóricas em muitas de suas obras, como é caso de Tempo impetuoso d'Estate (tempestade de verão) no terceiro movimento de As 
quatro estações.

\section{O sistema retórico-musical}

As composições barrocas apoiaram-se na organização do sistema retórico e, com exceção da memoria, suas seções foram adaptadas à música, cada qual com um diferente modo pensar os afetos: a) na inventio estudavam-se as possibilidades de cada afeto, selecionando-se elementos musicais - "tópicas" - por associações analógicas; b) na dispositio estabelecia-se o momento e a qualidade de cada afeto; c) na elocutio estabeleciam-se as "figuras retórico-musicais"; e d) na pronuntiatio, área de competência do intérprete, era recomendado deixar-se levar pela mesma paixão contida na composição - o "princípio da auto-afetação" é fundamental na prática musical dos afetos. (CANO, 2011, p. 68).

A inventio parte do princípio que a memória corresponde a um grande arquivo onde cada pensamento ocupa um lugar, o locus. Cada locus corresponde a uma pergunta - quem? que? onde? com ajuda de quem? por que? como? e quando? - que, juntas, formam o loci topici, um conjunto de dispositivos retóricos padrões disponíveis para ajudar o orador a descobrir tópicos, ideias para um discurso formal. (BUELOW, 1980). Na música, o sistema operacional da inventio passou a ser conhecido diretamente como loci topici ou "tópicas", tendo cada obra ao menos um locus. Segundo Cano (2011, p. 71-5), foi Mattheson que sistematizou a mais completa dessas redes, abrangendo 15 loci:

1. locus notationis, que possibilidades criativas existem, a partir da notação musical, a) no valor temporal das notas (com as repetições por aumentação ou diminuição); b) no intercâmbio de notas (como a inversão e retrogradação); c) na repetição ou resposta de temas musicais; e d) em imitações em cânone (como a fuga)?;

2. locus descriptionis, quais são as descrições musicais dos afetos na obra?;

3. locus generis et espécie, quais são os gênero e espécie (por exemplo, contraponto é um gênero e fuga uma espécie) da obra?; 
4. locus totius et partium, qual é sua instrumentação, quais são as partes solistas e os tuttis?;

5. locus causae efficientis, como a obra será narrada?;

6. locus causae materialis, como organizar suas fontes sonoras (dissonâncias, saltos melódicos, timbre, registro, intérprete etc)?;

7. locus causae formalis, qual sua forma (dança, ritornelli etc.)?;

8. locus causae finalis, para que público se escreve?;

9. locus effectorum, para que espaço (igreja, salão, praça, teatro etc.)?;

10. locus adjunctorum, quais seriam as representações musicais dos personagens (virtudes, defeitos, características corporais, posição social etc.) da obra?;

11. locus circumstantiarum, que época e lugar ela representa?;

12. locus comparatorum ou comparationis, como justapor seus elementos similares ou diferentes?;

13. locus oppositorum, como opor alturas e tempos na obra?;

14. locus exemplorum, que elementos de obras de outros compositores são usados?;

15. locus testimoniorum, que melodias conhecidas (como hinos de igreja, cantus firmi etc.) são usadas na obra?

$\mathrm{Na}$ dispositivo - que trata da estrutura -, é possível entender cada momento do discurso e estabelecer uma espécie de "mapa dos afetos" (ibid., p. 81).

Na elocutio, as ideias são colocadas com o objetivo de ajustar a correção da linguagem, a compreensão do discurso e seu embelezamento (decoratio) através da escolha das "figuras retóricas". A decoratio - a parte mais conhecida e estudada do sistema retórico e com ele, muitas vezes, confundida - se encarrega de transformar as expressões linguísticas e mover os afetos, exercendo sua função persuasiva. Nela, as figuras retóricas - operando por adição, subtração, substituição, permutação etc. - são determinantes para estabelecer um estilo para o discurso. Reboul (2004) as separa em: a) "figuras de palavras", que atuam sobre a matéria sonora do discurso como o trocadilho e a rima; b) "figuras de sentido", que atuam sobre a significação de palavras ou grupo de palavras - como a metáfora, a sinédoque, a hipérbole e a 
metonímia; c) "figuras de construção", que atuam sobre a estrutura da frase ou do discurso - como a elipse, o assíndeto, a reticência, a gradação e outras figuras de repetição (como a epanalepse); e d) "figuras de pensamento", que atuam na relação do sujeito com o objeto - como a alegoria e a ironia. ${ }^{4}$

Através de analogias, a música apropriou-se dos conceitos das figuras da linguagem, ora tomando emprestado a mesma terminologia retórica - com o uso de nomes gregos e latinos -, ora inventando novas figuras que expressassem procedimentos musicais próprios. A partir de definições e descrições de diversos tratados dos séculos XVII e XVIII, o catálogo escrito por Dietrich Bartel (1997), Musica poetica: rhetorical figures in German Baroque music, e o livro de Rubén López Cano (2011), Música y retórica en el barroco, listam de diferentes formas as figuras musicais - entre elas, as de repetição melódica, as baseadas em imitação, as formadas por dissonâncias, as de intervalo, as de hipotyposis (descrição musical de conceitos extra musicais), as sonoras, as formadas pelo silêncio etc.

A pronunciatio - encenação do discurso, sua entoação e pronúncia, seu ritmo, seu gestual - corresponde à performance musical. Nesta seção, os afetos ocupam lugar de destaque - segue-se o princípio da "auto-afetação". C. P. E. Bach afirmava que "um músico não pode comover aos demais a menos que ele também esteja comovido." (BACH apud CANO, 2011, p. 85-6).

\section{A teoria das tópicas e suas possibilidades em outros estilos}

Hoje retomou-se a perspectiva de se analisar a música a partir de sua dimensão retórica, especialmente as composições europeias dos períodos barroco e clássico. Autores contemporâneos, como Leonard Ratner (1980), têm proposto estudos relacionados à expressividade musical com base na "teoria das tópicas." Acácio Piedade (2007, p. 3) define tópicas como “objetos analíticos da significação musical", semelhantes àqueles que o musicólogo inglês contemporâneo Philip Tagg

\footnotetext{
${ }^{4}$ Grande parte dessas e de outras figuras serão conceitualizadas ao longo deste artigo. 
denomina de "musema"5 ou "sinédoque de gênero"6.

Com exemplos extraídos de um amplo universo que vai de The Rolling Stones, The Beatles a Cole Porter, passando por Tom Jobim e temas da tradição oriental, Tagg (2015) toma emprestado algumas figuras retóricas de linguagem para dar nomes ao que chama de "dispositivos processuais" comuns na melodia popular europeia e norte-americana. Ele, que "não faz distinção entre música popular ou erudita" (ULHÔA, 1999, p. 82), cita Charles Rosen (1997), para afirmar que

\begin{abstract}
quando a música clássica cruzou a rua da casa de ópera para a sala de concerto levou consigo toda uma série de relações entre estrutura musical e emoção ou movimento já existentes. (...) Quando os classicistas vienenses construíram seus movimentos em forma sonata, eles o fizeram, tenho certeza, sabendo que temas individuais, suas harmonias e orquestrações, seu fraseado etc. tinham certos afetos. Música na forma sonata não teria qualquer significado sem os afetos individuais e afetos variados de seus temas constituintes. Não seria lógico porque não haveria nenhum desenvolvimento, nenhuma narrativa, nenhuma sintaxe, sem os elementos contrastantes (ou semelhantes) que constituem os blocos de construção efetivos numa composição. Historicamente me parece bastante óbvio que se Bach morreu em 1750 e Mozart está escrevendo quartetos de cordas trinta anos mais tarde, e se todos eles estão aprendendo harmonia e contraponto, como de fato estavam, então seria bastante improvável que a noção de afeto tivesse desaparecido num tempo tão curto. (ULHÔA, 1999, p. 84-5).
\end{abstract}

Esta seção procura apresentar propostas sobre o uso da "teoria das tópicas" em situações diversas em termos de tempo e espaço geográfico, para além da música barroca e da Europa.

Ratner (1980) lista quais poderiam ser os assuntos tópicos para o discurso musical - figuras e progressões que formam um estilo - em compositores como Mozart, Beethoven e Haydn, entre outros. Para ele, a música do período clássico mesmo tendo optado pelos "contrastes frequentes" (RATNER, 1980, p. 30) - herdou do período barroco o ímpeto expressivo, que se vê evidenciado por passagens corridas, figuras conectivas etc.

Em sua gestualidade, as danças - incluindo minuetos, contra-danças e

\footnotetext{
${ }^{5}$ Os "musemas" são unidades mínimas de significação musical, tais como motivos, riffs, timbres, gestos, texturas, cadências, levadas, sequências de acordes etc. (ULHÔA, 1999, p. 81).

${ }^{6}$ Sinédoque é uma figura de linguagem na qual uma parte substitui o todo. (TAGG, 1992, p. 5) Por analogia, Tagg cunhou o termo "sinédoque de gênero" para nomear a possibilidade de existência de um fragmento musical ou musema que se refere a outro fragmento musical, desde que num estilo diferente daquele discutido. Por exemplo, scratch seria uma sinédoque de gênero para hip hop quando aparece como citação numa outra música. (ULHÔA, 1999, p. 81).
} 
outras - expressam alguns dos sentimentos que contribuíram para que compositores do classicismo escrevessem suas peças. Segundo Ratner, o reconhecimento das especificidades de cada padrão de dança é uma chave importante para desvendar-se a qualidade expressiva dessas composições.

Em obras de diferentes autores, Ratner (1980, p. 10-16) encontra danças como: o "minueto" (a mais popular da era clássica), em pulso ternário, expressando moderada alegria em virtude de seu andamento rápido, que se associava à elegância da corte e do salão7; a "contradança", muitas vezes composta em compasso binário, com melodias não ornamentadas, bem articuladas, brilhantes e alegres, como no Quinteto em Mi bemol maior, K. 614, de Mozart, do Ex. 1 (RATNER, 1980, p. 14); a "gavota", dança animada em compasso binário, com uma cesura após a terceira semínima do compasso (se escrita em 2/2), que acomodava uma melodia de elegância, equilíbrio e autocontenção; a "giga", geralmente em compasso 6/8, rápida, alegre e animada, como na Sinfonia $n^{\circ} 101$ em Ré maior, de Haydn, do Ex. 2 (RATNER, 1980, p. 15); e a "marcha", dança e cerimonial ao mesmo tempo, com compasso binário moderadamente rápido e ritmos pontilhados, que tinha propriedade de acelerar o espírito.

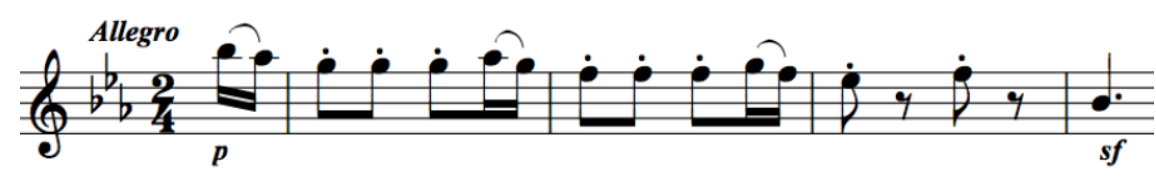

Ex. 1 - contra-dança em Mozart

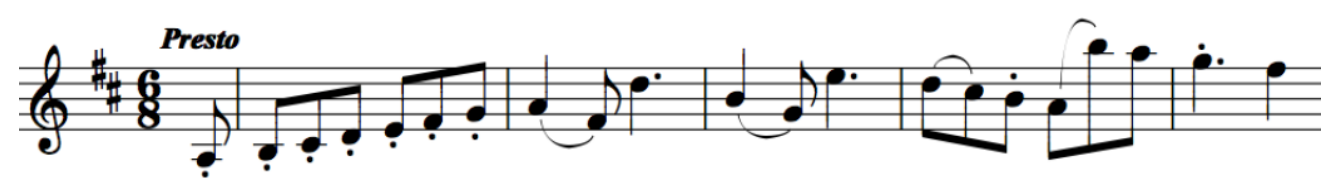

Ex. 2 - giga em Haydn

Além das danças, ele associa as tópicas na música clássica ao uso de estilos que classifica como "música militar e de caça", "abertura francesa", "musette, pastoral", "música turca", "sentimental", "estrito" e "fantasia” etc.

Embora pertençam a uma realidade distante, Piedade acredita que

\footnotetext{
7 Ratner observa que outras danças populares - valsas, ländlers, allemandes etc. - apareciam disfarçadas, em autores clássicos, como minuetos de caráter mais simples.
} 
referências como as descritas - sendo um canal para a compreensão da significação musical - poderiam nos orientar a elaborar uma "teoria das tópicas" para a música brasileira. O desafio consistiria em encontrar em uma memória coletiva quais seriam aquelas relacionadas à construção de nossas identidades culturais. Para ele, o trabalho de visualizar uma tópica envolve uma hermenêutica usada no campo da análise musical. (PIEDADE, 2007, p. 3). Com esse raciocínio, sugere diversas propostas e nomenclaturas bem próprias e curiosas, como o estilo "brejeiro", brincalhão e desafiador, exibindo audácia e virtuosismo, de forma graciosa e, principalmente, interesseira, individualista e maliciosa, que pertence a gêneros como o choro e usam variações melódicas, rítmicas e harmônicas que desafiam músicos acompanhadores; o "nordestino", que apresenta escalas mixolídias e/ou padrões rítmicos do baião, que além de pertencer a gêneros populares do nordeste encontrase em composições eruditas nacionalistas, simbolizando uma suposta identidade brasileira; e o "caipira", que evoca o mundo rural imaginário do sudoeste e centro brasileiros, nos ponteios da viola de arame e duetos vocais em terças e sextas paralelas. (PIEDADE, 2007, p. 4-5).

Propostas como essas, entre outras que sugere, parecem fazer mais sentido quando analisamos especificamente a música dos chorões, esta herdeira direta de danças clássicas europeias que aqui aportaram desde meados do século XIX. Alguns procedimentos e significados musicais, como os descritos por Ratner, chegaram do velho continente através das polcas, valsas, mazurcas, schottishes, quadrilhas etc., definindo estilos que tiveram grande importância na criação do choro.

A partir das redes de tópicas relacionadas em tratados barrocos, dos aspectos e exemplos propostos por Ratner no âmbito do classicismo e das questões e possibilidades sugeridas por Piedade em relação à música brasileira, parece apropriado pensarmos na perspectiva de se construir uma rede de tópicas que simbolize as práticas de um compositor ou intérprete contemporâneo de choro.

A construção dessa rede - formada por códigos, tradições, e procedimentos criados e compartilhados desde fins do século XIX na "memória coletiva" do grupo de chorões - poderia ter como ponto de partida questões semelhantes às elaboradas pela lista de Mattheson: 
a) A que gênero pertence a peça musical? Um choro, uma valsa, um maxixe etc.? Esta tópica, assim como a seguinte, se assemelha ao locus generis et espécie, da rede de Mattheson;

b) Qual seu estilo? Antigo, novo, tradicional, moderno?

c) Qual seu fraseado? Qual sua densidade melódica, seus intervalos, suas ideias rítmicas, figuras melódicas, cadências e sequências harmônicas?

d) Qual sua forma? Uma, duas, três partes e de quantos compassos cada? Apresenta introdução, coda, pontes? Esta tópica se assemelha ao locus causae formalis;

e) Que afetos representam a peça? Alegre, melancólico, evocativo, doce etc.? Esta tópica, assim como a seguinte, se assemelha ao locus descriptions;

f) Qual seu andamento? Lento, médio, ligeiro?

g) Que título melhor representa a peça? Nome de um ser, de um lugar, de uma época, de uma ação etc.? Esta tópica se assemelha também ao locus circumstantiarum;

h) Que pessoas, lugares ou coisas a peça lembra? Há alguma citação que se refira a um compositor, um estilo, por exemplo? Esta tópica se assemelha aos locus exemplorumn e locus testemoniorum;

i) Que instrumentação e sonoridade são adequadas para a peça? Conjunto, duo, trio etc.? Com ou sem percussão, com instrumentos tradicionais ou mais modernos etc.? Esta tópica se assemelha ao locus totius et partium;

j) Que arranjo é compatível com a peça? Com improvisações, com muitas convenções escritas etc.? Esta tópica, assim como as duas seguintes, se assemelha aos locus causae materialis;

k) Que dinâmicas, efeitos e ornamentações devem ser convencionadas?

1) Que instrumentista deve interpretar a peça? Os de formação popular, clássica etc.?

m) Que lugar é apropriado para se tocar a peça, para que público? Teatro, estúdio, ar livre, em ambiente silencioso, ruidoso, para muitas ou poucas pessoas, para jovens ou idosos etc.? Para dançar ou para ouvir? Esta tópica se assemelha aos locus effectorum e locus causae finalis.

Essas propostas, construídas a partir de padrões de recorrência da 
memória coletiva dos chorões, não têm a pretensão de querer explicar todas as composições e execuções desse grupo. Mesmo porque uma criação musical costuma transcender esquemas e modelos. Mas, do ponto de vista da análise musical, semelhantes redes de tópicas servem como um exercício para refletirmos sobre aspectos das práticas do choro e de outros gêneros da música instrumental brasileira.

\section{As figuras retórico-musicais e o choro}

As "figuras retóricas" fazem parte de um conjunto de operações usadas para transformar o modo habitual da linguagem - uma expressão usual dá lugar a outra de caráter inesperado. Elas, como vimos, definem um estilo para um discurso, objetivando a criação de sua beleza e o movimento de seus afetos. E são retóricas por seu papel persuasivo.

Ao utilizar recursos que pudessem alterar sua gramática, a música tomou emprestada ideias do discurso verbal. Uma série de dispositivos - como repetições, descrições, ornamentos, pontes e seções de transição, contrastes, interrupções, silêncios, sequências, modos etc. - passaram a ser empregados com a função de enfatizar a força expressiva do discurso musical.

Foi na música vocal europeia que as "figuras retórico-musicais" surgiram e criaram as ferramentas para apoiar as intenções dos textos. Elas só passaram a ser incorporadas à música instrumental a partir da primeira metade do século XVII. O vínculo entre as retóricas dos discursos verbal e instrumental chegou a atingir níveis bastante complexos de codificação, embora reconheça-se atualmente que muitas figuras eram dispositivos destinados apenas a decorar e elaborar sobre uma representação afetiva básica. (BUELOW, 1980).

Os tratadistas apontavam a melodia e a harmonia como os elementos mais afetados pelas figuras retóricas. Ao pesquisar tratados barrocos, Bartel (1997) elaborou um catálogo de figuras usadas no estilo alemão. Cano complementou seu trabalho, incluindo outras nacionalidades e figuras, classificando-as por seus modos de operação. Entre as de "adição", por exemplo, há as que atuam pelo uso da “repetição." De uma maneira ampla, a repetição relaciona-se à unificação de uma 
obra, sendo um elemento esperado entre motivos, frases e seções de diversas formas musicais. A repetição tem a ver com a insistência - repetimos o que não se entendeu bem, o que não queremos esquecer; repetimos o que merece ser sublinhado (CANO, 2011, p. 108). Ela é um dispositivo fundamental na estruturação das músicas populares e danças, como é o caso da polca, da valsa, do maxixe etc. que usam a forma rondó, com partes que se repetem.

A fim de adequar alguns conceitos retóricos ao repertório do choro, selecionei aqui figuras que pudessem traduzir alguns procedimentos composicionais ou interpretativos do gênero. Procurei estabelecer um paralelo entre definições e exemplos encontrados por Bartel e $\mathrm{Cano}^{8}$ e esses procedimentos, considerando que a música europeia e o tonalismo - e sua estruturação a partir do período barroco, passando pelo classicismo e o romantismo - tenham exercido grande influência na música popular brasileira do século XIX. ${ }^{9}$

As figuras retórico-musicais usadas no barroco estão aqui ilustradas por padrões encontrados em choros e gêneros afins. Não fossem as limitações de espaço do texto, seria possível ampliar o número de exemplos e figuras. É verdade que as poucas que sugiro nem sempre se mostram, hoje, herdeiras fiéis dos antigos afetos, que muitas vezes se associavam à função da música em práticas religiosas, por exemplo.

Dentre as figuras que afetam a melodia por "repetição", por exemplo, está a anaphora (anáfora), que consiste na reprodução de um mesmo fragmento no início de diversas unidades - como em Der volkommene Capellmeister, de Mattheson, em Sol-Lá-Si-Dó (c. 1-2 e c. 2-3), no Ex. 3 (BARTEL, 1997, p. 189). Na linguagem, ela está na repetição da mesma palavra ou grupo de palavras no princípio de frases ou versos consecutivos, como nos versos “é pau, é pedra, é o fim do caminho/

\footnotetext{
${ }^{8}$ Bartel e Cano, que apresentam as divergentes definições e terminologias dos autores que citam, procuram elaborar listas de figuras (com ilustrações) a partir de alguns conceitos comuns encontrados em tratados de música poética (como os de Joachim Burmeister, Johannes Nucius, Athanasius Kircher, Cristoph Bernhard e Johann Adolph Sheibe); em tratados de retórica oratória e literária (como os de Quintiliano, Miguel de Salinas e Bartolomeu Jiménez Patón); e em pesquisas de musicólogos contemporâneos (como as de Helena Beristáin, George Buelow, Ursula Kirkendale, Robert Toff e Ferrucio Civra etc.).

${ }^{9} \mathrm{Tal}$ influência, entre outras coisas, pode estar no fato de alguns solistas e compositores brasileiros terem sido músicos "de escola" - Joaquim Callado, por exemplo, era titular da cadeira de flauta do Conservatório de Música fundado em 1841 (hoje, Escola de Música da UFRJ).
} 
é um resto de toco, é um pouco sozinho", de Tom Jobim. Segundo Kircher, era utilizada na música barroca para expressar as paixões mais violentas, crueldade, desprezo. (CANO, 2011, p. 110). Em outro contexto, aparentemente apenas com o sentido da insistência, a primeira parte de Matuto, de Ernesto Nazareth, do Ex. 4, apresenta um caso de anáfora. ${ }^{10}$

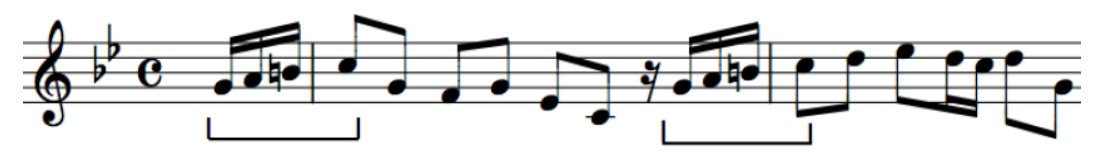

Ex. 3 - anaphora em Mattheson

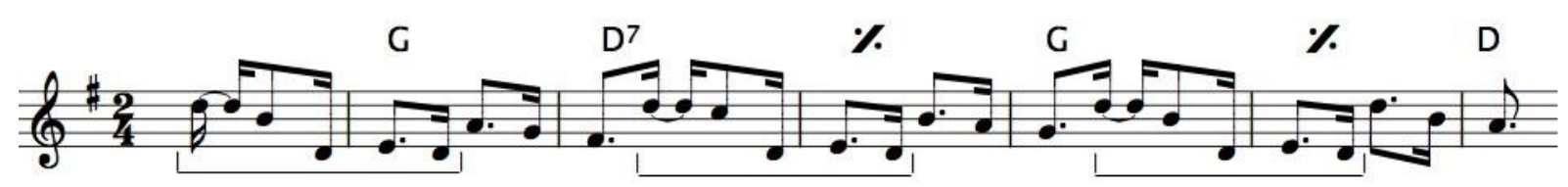

Ex. 4 - anaphora em Matuto

A synonimia (sinonímia) consiste na repetição de um fragmento musical transportado a outro nível (altura), como em Ich liege und schalafe, de Heinrich Schütz (1585-1672), no Ex. 5 (CANO, 2011, p. 119). Em linguagem, está na relação entre palavras de significados semelhantes, como "bonito e lindo", "feliz e alegre" etc.

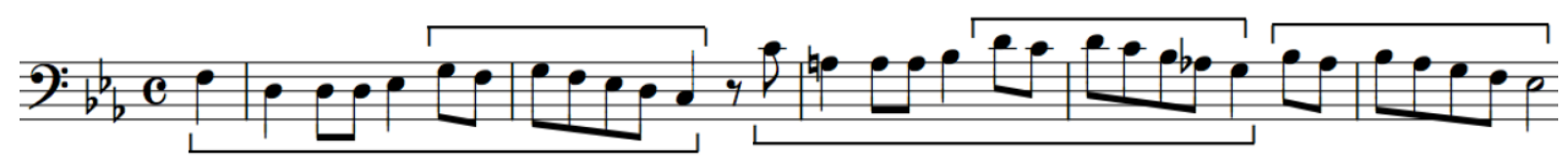

Ex. 5 - synonimia em Heinrich Schütz

Nos choros, esta figura pode acontecer em sequências harmônicas ${ }^{11}$, como no início da polca Apanhei-te cavaquinho, de Nazareth, no Ex. 6, ou sobre um mesmo acorde, como no início do choro Picadinho à Baiana, de Luperce Miranda, no Ex. 7 neste caso, com caráter de arpejo ornamentado.

\footnotetext{
${ }^{10}$ Figuras de repetição, como a anáfora e a epístrofe, classificadas por Tagg (2015) como "dispositivos processuais", são encontradas também na melodia popular europeia e norte americana.

${ }^{11}$ Tagg (2015) inclui a sequência como um dos dispositivos processuais recorrentes na música popular. Ele exemplifica com a conhecida canção Autumn leaves, do exemplo abaixo.
} 


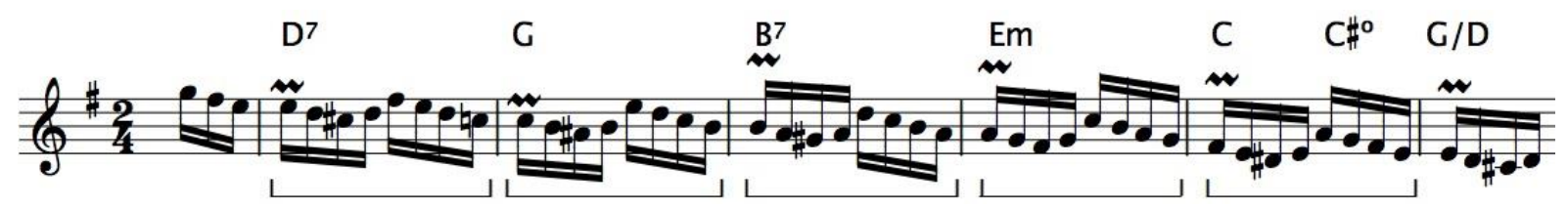

Ex. 6 - synonimia em Apanhei-te cavaquinho

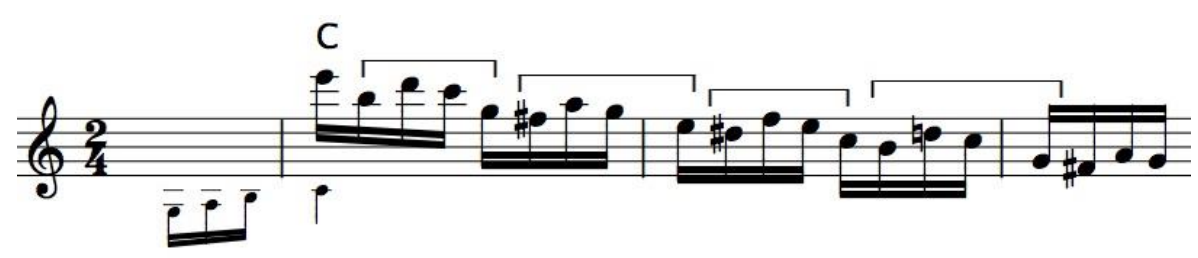

Ex. 7 - synonimia em Picadinho à baiana

A gradatio (gradação) consiste na repetição de um fragmento musical que ascende ou descende, por grau conjunto, em forma de sequência. Equivale a "dispor as palavras na ordem crescente de extensão e importância" (REBOUL, 2004, p. 129), a exemplo dos versos "ó não guardes, que a madura idade/ te converta essa flor, essa beleza/ em terra, em cinzas, em sombra, em nada", de Gregório de Matos. Segundo Kircher, usa-se a gradatio ascendente - como a do fragmento da Cantata Jesus meine Seele, BWV 78, de J. S. Bach, no EX. 8 (CANO, 2011, p. 122) - para expressar o amor divino ou a busca do reino celeste (CANO, 2011, p. 121).

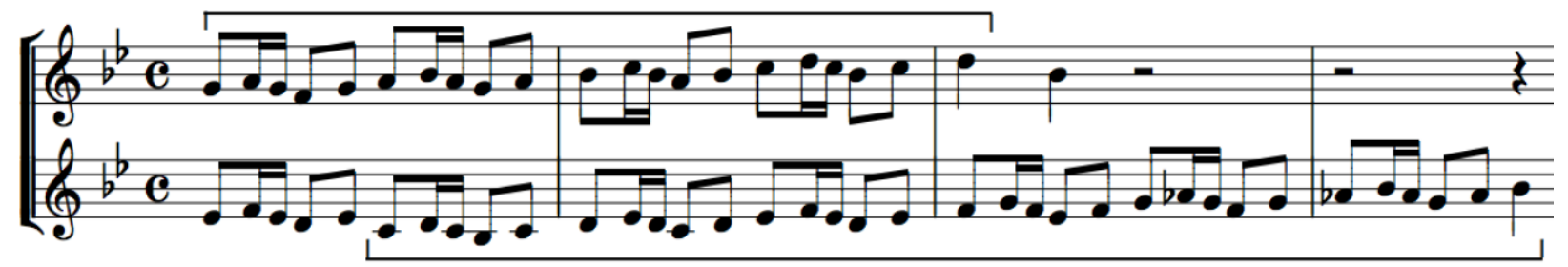

Ex. 8 - gradatio em J. S. Bach

Mesmo aparentemente sem tais conotações, a valsa brasileira Alma brasileira, de Fernando Magalhães e Judas Isgorota, do Ex. 9, parece sugerir em seu título e suas frases iniciais ascendentes um certo caráter evocativo e espiritual. ${ }^{12}$

\footnotetext{
${ }^{12}$ Os pesquisadores Acácio Piedade e Allan Falqueiro (2007) identificam figuras gradatio no início da canção Eu sei que vou te amar, de Tom e Vinicius.
} 


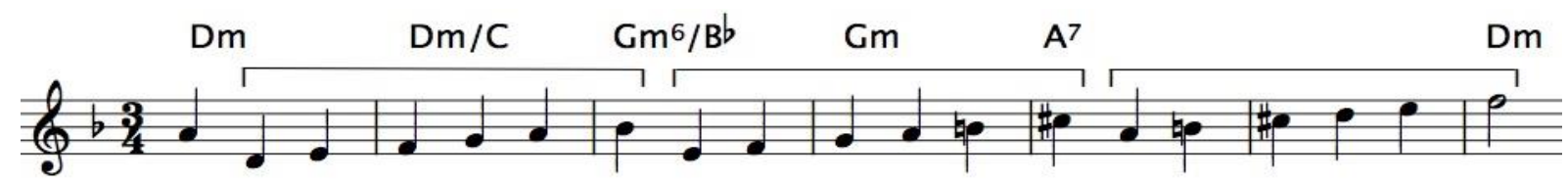

Ex. 9 - gradatio em Alma brasileira

As figuras relacionadas à "descrição" abrangem aspectos extra musicais, como as evocações ou imitações de sons de animais, de instrumentos musicais ou de coisas, através do uso de desenhos melódicos, estruturas harmônicas, ritmos etc. Esses processos descritivos, no estilo barroco, podem vincular-se tanto aos conceitos de "metáfora" quanto os de "alegoria." Bukofzer dá um exemplo de alegoria musical.

(...) é comum (...) que ao aparecer em um texto a palavra "cruz", J. S. Bach utilize sustenidos. Isto se deve a que em alemão, kreutz é um dos nomes que se empregam para denominar-se o signo de sustenido “\#”. Não é estranho, continua, que o trompete apareça nas partituras bachianas [sempre em sua parte superior] como alegoria da "majestade [e supremacia] de Deus". (CANO, 2011, p. 134).

Dentre as figuras descritivas, está a anabasis, que consiste em uma linha melódica ascendente, como na Cantata Der Himmel lacht! Die Erde jubiliert, BWV 31, de J. S. Bach, no Ex. 10 (ibid., p. 137). Segundo Kircher, com esta figura expressam-se exaltação, ascensão, ou coisas semelhantes. (ibid., p. 136). Tem, de certa forma, conotação similar a gradatio ascendente.

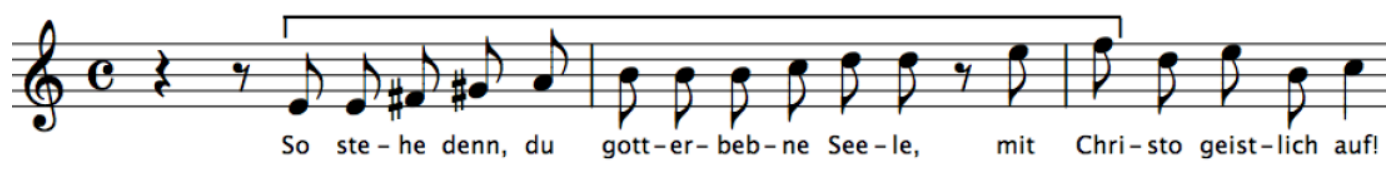

Ex. 10 - anabasis em J. S. Bach

Curiosamente, o tema principal da valsa Subindo ao céu (no início de sua primeira parte), de Aristides Borges, no Ex. 11, procura descrever o título da peça através de uma ascensão melódica em degraus. 


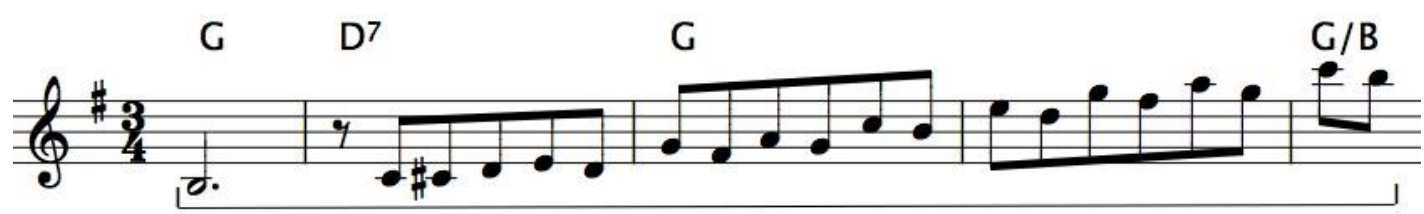

Ex. 11 - anabasis em Subindo ao céu

A catabasis consiste em uma linha melódica descendente, como em Miserunt ergo sortem, Jonas, de Giacomo Carissimi (1605-1674), no Ex. 12 (CANO, p. 138). Para Kircher, esta figura expressa sentimento de inferioridade, humilhação e envelhecimento. (ibid., p. 138).

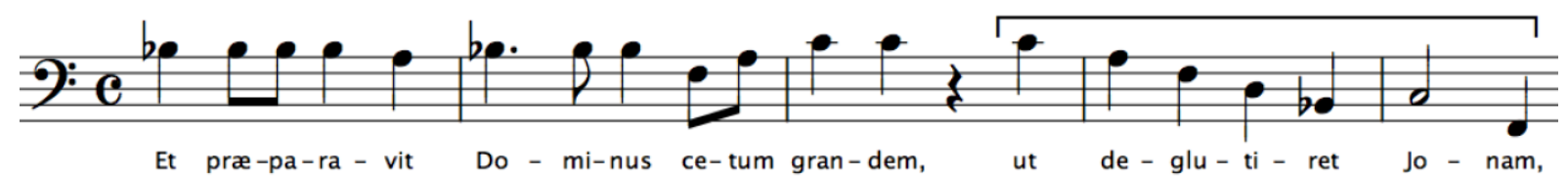

Ex. 12 - catabasis em Giacomo Carissimi

Nas modinhas brasileiras, as linhas melódicas descendentes são comuns e podem relacionar-se a sentimentos de melancolia e paixão. O musicólogo brasileiro Bruno Kiefer (1986) associa tais conduções à "nossa tristeza" e os grandes saltos de melodia, ou arpejos, que as precedem a "verdadeiros suspiros". O início da valsa "sentimental" De coração a coração, de Jacob do Bandolim, no Ex. 13 - composta em homenagem a seu cardiologista - , é composto de várias frases descendentes na melodia e no contraponto, que poderiam ser consideradas casos de catabasis.

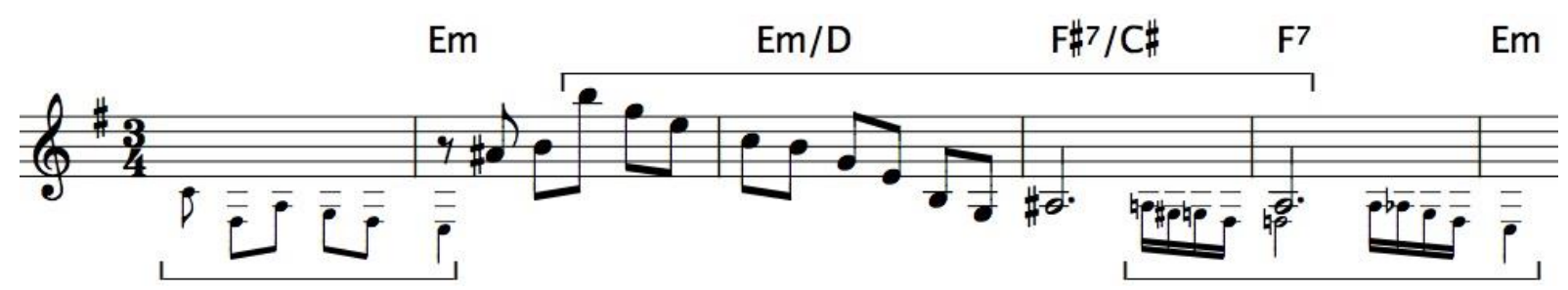

Ex. 13 - catabasis em De coração a coração

A prosopopeia (personificação) é uma representação musical dos afetos, pensamentos ou características de pessoas ausentes ou coisas inanimadas. Em um discurso, consiste em falar por um orador fictício (REBOUL, 2004, p. 251) ou 
emprestar a seres inanimados, ausentes ou mortos, sentimentos e palavras (KOOGAN; HOUAISS, 1993, p. 683), como em “as pedras choram, os regatos sorriem." Esta figura requer que o intérprete convença o ouvinte da presença da pessoa (ou coisa) evocada (CANO, 2011, p. 145). Há choros que, já na própria composição, podem sugerir o estilo interpretativo de um músico - como é o caso do sentimental Evocação a Jacob, de Avena de Castro, no Ex. $14^{13}$ (SÈVE; SOUZA; DININHO, 2011, p. 94).

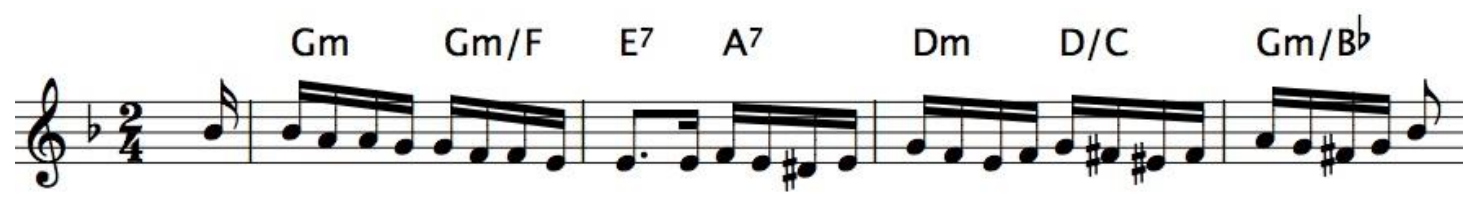

Ex. 14 - prosopopeia em Evocação a Jacob

A assimilatio (assimilação) é uma simulação que um instrumento realiza do som de outro instrumento ou coisa. Um exemplo clássico de assimilatio pode-se encontrar em As quatros estações de Vivaldi, em que sons de aves, cachorros, chuva, vento etc. ilustram cada período aludido. (CANO, 2011, p. 146). A primeira parte do choro Língua de preto, de Honorino Lopes, no Ex. 15, simula musicalmente (através de sucessões de oitavas) o jeito de falar de um preto velho e Canarinho teimoso, de Altamiro Carrilho, está entre os choros que realizam imitações de gorjeios de passarinhos.

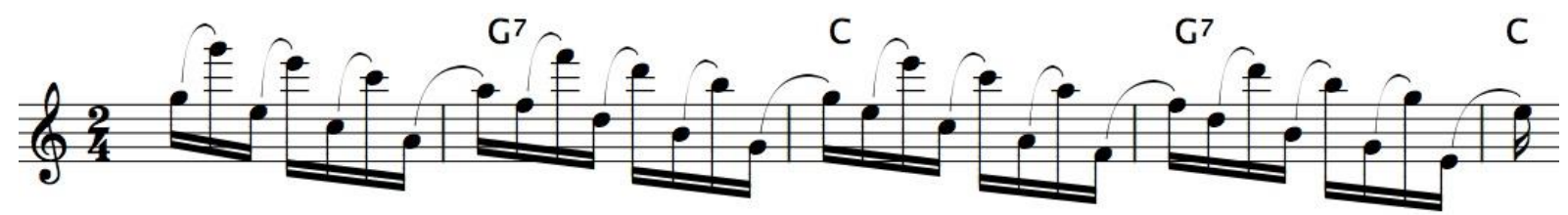

Ex. 15 - assimilatio em Língua de preto

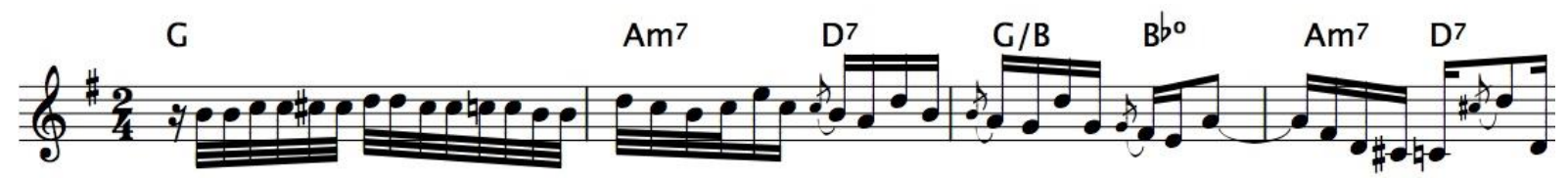

Ex. 16 - assimilatio em Canarinho teimoso

\footnotetext{
${ }^{13}$ Uma análise retórica poderia associar o título da obra à uma gradatio descendente e de caráter melancólica de seu início (c. 1-3).
} 
O que Cano classifica como paragoge de Kircher consiste na descrição de ações. No Cobatimento di'Tancredi et Clorinda, Monteverdi descreve, no Motto del Cavallo (c. 18-37), o crescendo galopante de um equino. (CANO, 2011, p. 147). Com o intuito de descrever ações sugeridas pelas composições, é muito comum que alguns choros sejam nomeados com verbos no gerúndio14, como é o caso de Escorregando, de Nazareth, no Ex. 17, cujo início da melodia sinuosa e descendente em degraus parece sugerir movimentos de desequilíbrio - com quedas em etapas (c. 1-3 e c. 5-7) em direção ao grave (chão) - seguidos de recuperações e estabilidades efêmeras (c. 3-5 e c. 7-9) - com o uso de notas repetidas na região média.

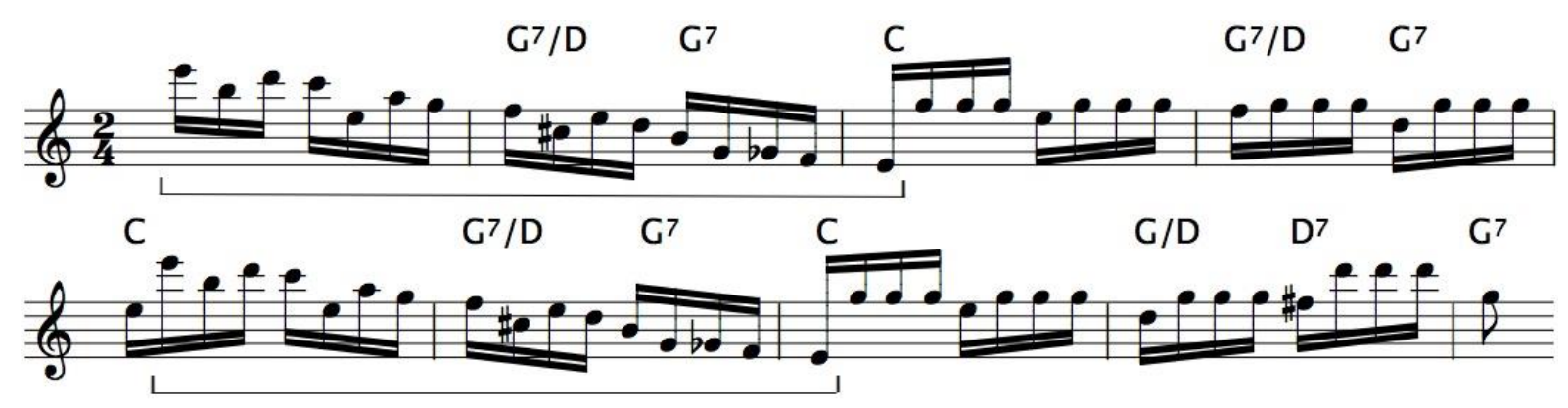

Ex. 17 - paragoge de Kircher em Escorregando

Não referenciada por nenhum tratadista barroco, o epifonema seria uma anotação no título de uma peça indicando o significado musical a ser desenvolvido, ou um comentário no princípio ou ao final de um discurso musical. Segundo a musicóloga Ursula Kirkendale - que introduziu e conceituou musicalmente esta figura retórica -, no Canon a dos per augmentationem, da Oferenda Musical, de J. S. Bach, Notulis crescentibus crescat fortuna regis (como as notas crescem, a fortuna do rei cresce) é um título que alude ao significado da alegoria oculta no aumento de duração nas notas do tema (CANO, 2011, p. 149). Em retórica literária, o epifonema consiste em uma exclamação sentenciosa com que se termina uma narrativa ou um discurso, como a dos versos "Mísera sorte! Estranha condição!", de Luís de Camões.

Embora, neste caso, seja mais complicado estabelecer-se um possível paralelo com a figura, observo que muitas edições de partituras relacionadas ao

\footnotetext{
${ }^{14}$ Tal característica talvez seja uma herança da própria notação musical, que costuma usar palavras como acellerando, ritardando etc. para indicar ações interpretativas.
} 
choro costumam trazer não só a indicação do gênero a ela relacionado, mas também indicações de seu caráter. Caracterizadas como tangos, polcas, polcas-lundu, valsas etc., as peças de Ernesto Nazareth (CURY; MACHADO, 2007) apresentam, nas partituras, indicações interpretativas (algumas genuínas) em termos como dolcemente, gingando, afetuoso, gracioso, saltitante, misterioso, dolente, plangente, suave, enérgico, com delicadeza, com sentimento, com entusiasmo, com elegância etc. No repertório chorístico há casos de termos como esses chegarem aos títulos das peças, como é o caso de Dolente, de Jacob do Bandolim, e Plangente, do próprio Nazareth.

A "dissonância", uma figura que afeta a harmonia, foi dos recursos retórico-musicais mais efetivos no período barroco. Ela deveria ser interpretada em contraste com outros elementos, a fim de que os ouvintes a assimilassem como uma figura carregada de significado. Porém, ela mudou de conceito e caráter através de diferentes épocas e estilos. Algumas dissonâncias que eram comuns (como antecipações, apojaturas ou retardos) são hoje recursos harmônicos habituais, vulgarizados - não mais contradizem a gramática musical, pois foram a ela incorporados. A transitus notae é o que conhecemos como nota de passagem. Visto que os choros são construídos, em grande parte, por arpejos, melodias ornamentadas e escalas diatônicas - o que o assemelha às composições barrocas - , é muito raro encontrarmos peças do gênero sem inúmeras notas de passagem e inflexões como bordaduras, cambiatas etc. ${ }^{15}$ Há as figuras quasi transitus - nota de passagem que, por sua duração, acento ou ornamentação destaca-se mais que as notas reais (nos choros, há diversos exemplos em síncopes dentro de um tempo) - e transitus inversus - dissonância produzida no tempo forte de um compasso, originada por uma nota de passagem -, esta recorrente em choros de Pixinguinha e outros chorões, em apojaturas em inícios de compassos.

Cano cita ainda as figuras que afetam vários elementos musicais simultaneamente, como as que adicionam, subtraem ou trocam e/ou substituem registros, sinais, modos ou outros conteúdos musicais a uma nota, um fragmento, uma seção ou um movimento. A "adição" de um tipo de material ou componente

\footnotetext{
${ }^{15}$ Exemplos de inflexões melódicas relacionadas ao choro estão em A estrutura do choro, de Carlos Almada (2006).
} 
pode ocorrer por "variação-incremento" (a uma nota ou a um fragmento), "amplificação" (a uma seção ou movimento), “dúvida” (escondendo o significado ou direção de uma unidade) ou "acumulação" (aglomerando elementos em uma mesma unidade). A "subtração" pode ocorrer por "omissão" (deixando incompleta uma unidade musical) ou "silêncio" (introduzindo pausas com significados específicos).

A polysyndeton (polissíndeto), uma figura de "acumulação" por adição, é uma ênfase que se prolonga em partes similares de uma unidade, de uma mesma voz - como no motivo que se repete sucessivamente no fragmento da Cantata Aus der Tiefen rufe ich, Herr, zu dir, BWV 131, de J. S. Bach, no Ex. 18 (CANO, 2011, p. 187). Na linguagem, consiste na repetição sequencial de conjunções entre palavras e orações, como nos versos "canto, e canto o presente, e também o passado e o futuro", de Fernando Pessoa. Ela serve para realçar os afetos, fortalecendo o que é dito.

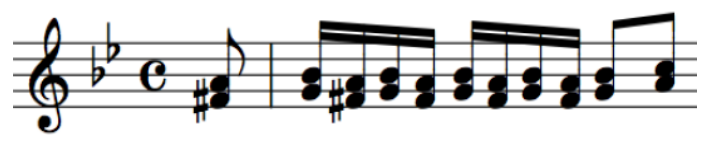

Ex. 18 - polysyndeton em J. S. Bach

O choro Carioquinha, de Waldyr Azevedo, no Ex. 19, inicia com dois motivos (o primeiro no c.1 e o segundo, uma quarta acima, no c. 5), cada qual com cinco repetições consecutivas, numeradas no exemplo abaixo.

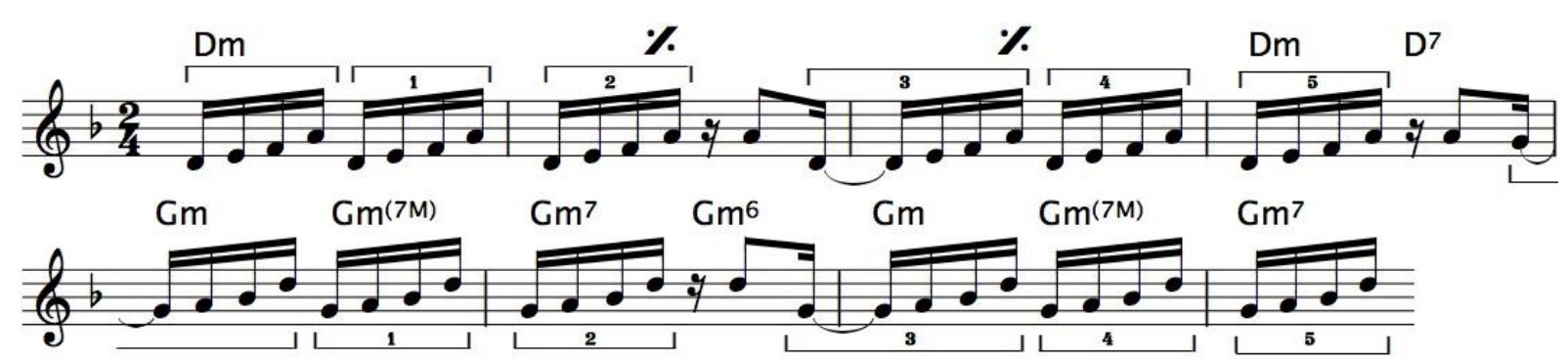

Ex. 19 - polysyndeton em Carioquinha

O asyndeton (assíndeto), uma figura de "subtração" por adição, caracteriza-se pela repetição recorrente e ininterrupta de um mesmo fragmento, uma mesma figura, suprimindo-se termos de ligação - como a conjunção "e" em "vim, 
vi, venci", na linguagem (REBOUL, 2004, p. 245) e o seguinte trecho da Cantata BWV 131, de J. S. Bach, no Ex. 20 (CANO, 2011, p. 198), na música.

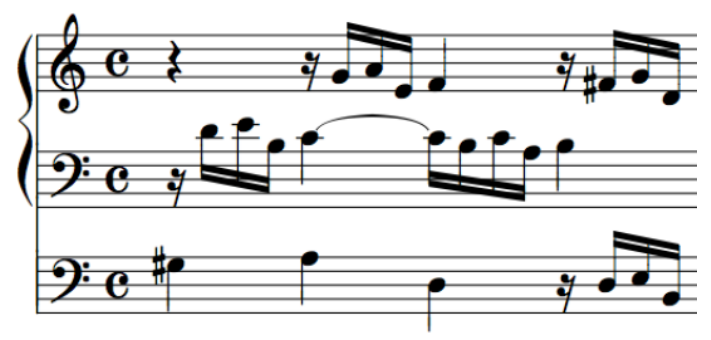

Ex. 20 - asyndeton em J. S. Bach

É uma figura usual nos choros, em conversas ente melodias e contrapontos, como no fragmento da polca O gato e o canário, de Pixinguinha e Benedito Lacerda, do Ex. 21, em que a dupla usa dois motivos que se repetem e se intercalam em vozes diferentes.

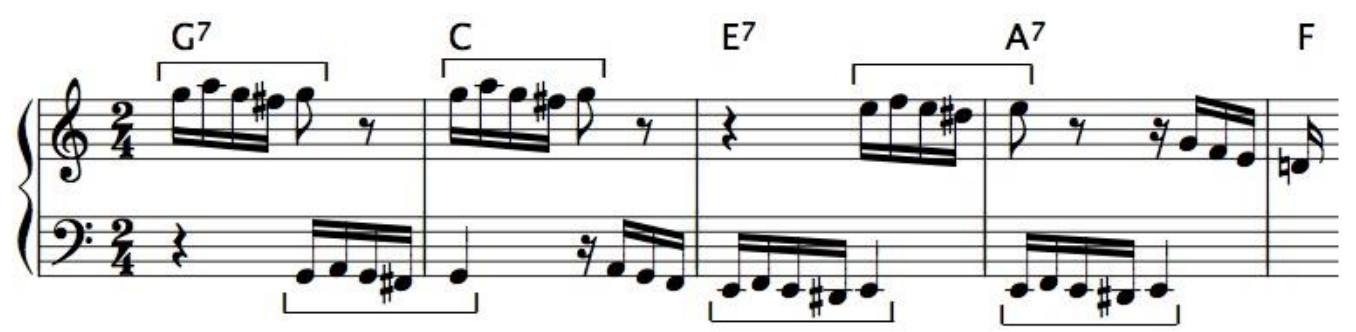

Ex. 21 - asyndeton em $\mathrm{O}$ gato e o canário

A dubitatio, figura de "adição" por dúvida, está relacionada à indecisão sobre o curso a ser tomado em um movimento musical. Segundo Forkel (1749-1818), a figura da dúvida pode ser expressa por uma "parada inesperada", no Ex. 22 (BARTEL, 1997, p. 244), em uma frase musical ou por uma "modulação duvidosa", no Ex. 23 (ibid., p. 244). Na linguagem, poderia ser ilustrada pelos versos "ser ou não ser/ eis a questão", de Shakespeare.

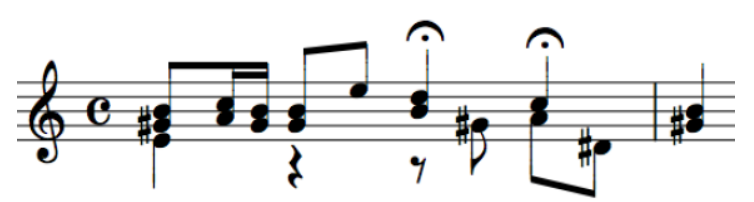

Ex. 22 - dubitatio em "parada inesperada" 


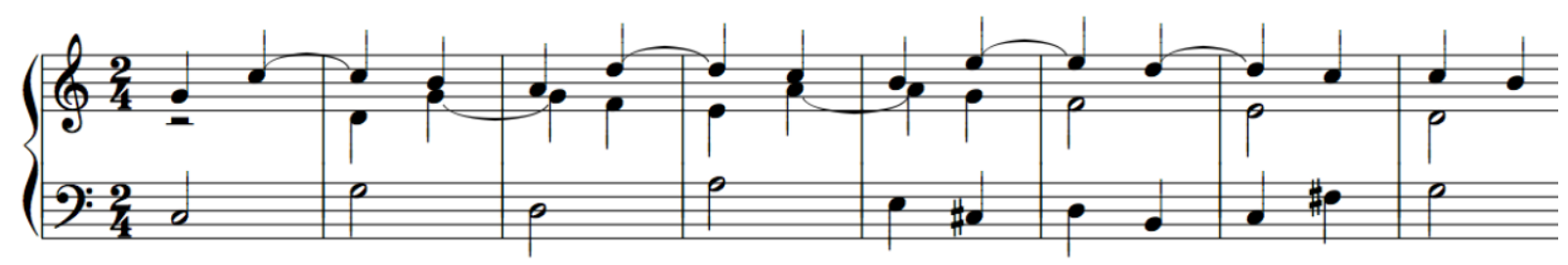

Ex. 23 - dubitatio em "modulação duvidosa"

Valsas e tangos de Nazareth, ao final de períodos ou seções, muitas vezes indicam fermatas precedidas por motivos desacelerados 16 , supostamente para modificar o caráter dançante de algumas de suas composições. ${ }^{17}$ É o que acontece nos compassos (c. 2-3) que antecedem a cadência conclusiva (c. 4-5) da primeira parte do tango Ouro sobre azul, de Nazareth, no Ex. 24 (CURY; MACHADO, 2007, p. 122).

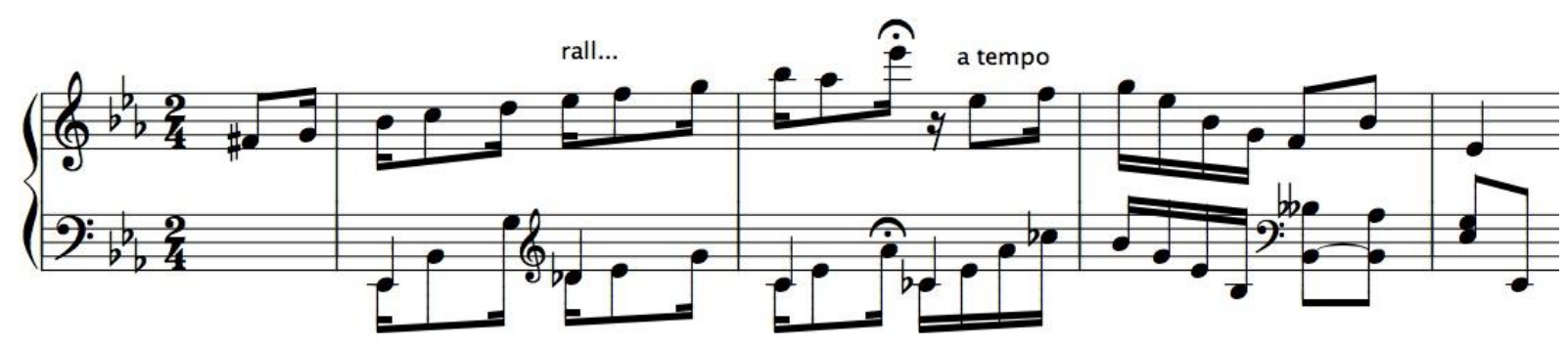

Ex. 24 - dubitatio em Ouro sobre o azul, para piano

É da tradição do choro que músicos acompanhadores (violonistas, cavaquinistas etc.) tenham habilidade de intuir harmonias a partir apenas da audição de melodias. Segundo Baptista Siqueira, flautistas, como Joaquim Callado,

costumava[m] incentivar o gosto pelo choro, aguçando as qualidades musicais inatas dos acompanhadores de ouvido, arranjando tropeços através de modulações exaustivas empregadas nas "polcas de serenata." (...) A finalidade de tais peças era jocosa: fazer cair o tocador de cavaquinho. (SIQUEIRA, 1969, p. 139).

Nomes associados a desafios de técnica instrumental ou de percepção harmônica, dados à polcas - do tipo Caiu, não disse!, Não caio noutra, Apanhei-te cavaquinho - , tornaram-se uma tradição dentro do choro. Pixinguinha, por exemplo,

\footnotetext{
${ }^{16}$ Neste caso, aparece também a suspensio, outra figura de "dúvida", que consiste em uma interrupção, suspensão ou um retardamento do discurso musical - como se dá na desaceleração dos motivos rítmicos do primeiro compasso no fragmento abaixo da Cantata BWV 131, de J. S. Bach (CANO, 2011, p. 180). Na retórica literária, refere-se ao retardamento de um pensamento.

${ }_{17}$ Vários aspectos interessantes para se conhecer a obra de Nazareth são relatados no livro $O$ Enigma do homem célebre, do músico Cacá Machado (2007).
} 
compôs Acerta o passo e Segura ele, Dante Santoro, Harmonia selvagem, José Toledo, Cuidado violão, Abel Ferreira, Sai da frente, Severino Araújo, Espinha de bacalhau etc. Sandroni (2002, p. 78) diz que Mário de Andrade considerava títulos como esses um "tesouro verdadeiro de argúcia, pernosticidade, meiguice e humorismo". Ele comenta ainda que não poderiam, certamente, ser dados a valsas e a polcas de estilo europeu, e associa suas origens ao humor característico dos lundus.

São peças que, em seus próprios nomes, alertam para eventuais armadilhas propostas pelo compositor, como é o caso do choro em Dó maior Cuidado colega, de Pixinguinha e Benedito Lacerda, no Ex. 25, que, além de passagens difíceis para os solistas, apresenta modulações bruscas nos compassos iniciais (para Ré bemol maior, em c.5, e para Mi maior, em c. 8-9).

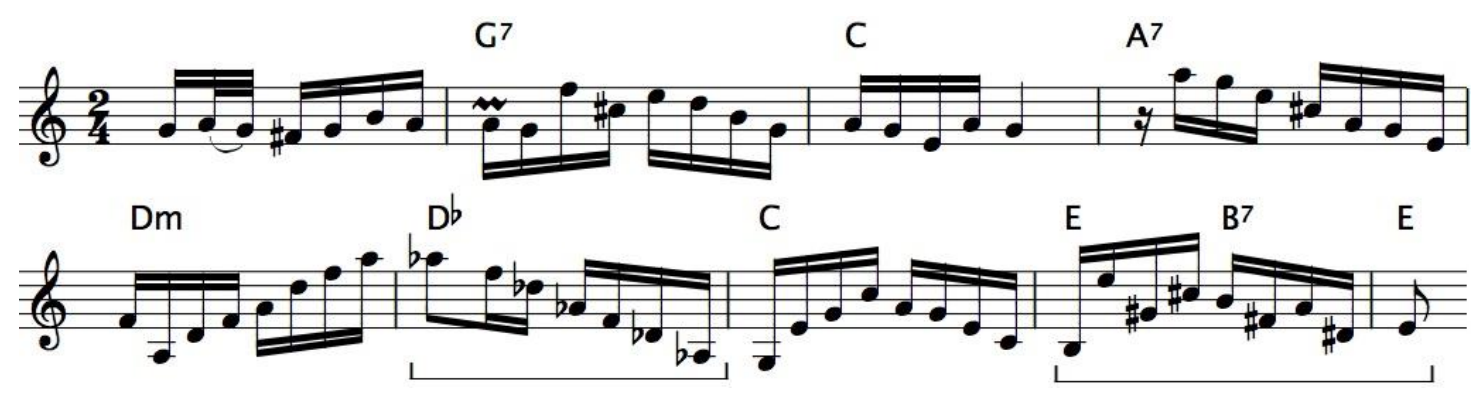

Ex. 25 - dubtatio em Cuidado colega

A abruptio, uma figura de "subtração" por omissão, corresponde a uma interrupção ou um final súbito, imprevisto. Segundo Mattheson, serve como uma representação de emoções excitantes. (CANO, 2011, p. 188). Como figura de linguagem, consiste em alternar os discursos dos diferentes personagens em diálogo, ou deste com a narração, de maneira brusca. Nos choros, ela poderia ser representada pelo que conhecemos em música popular como "breque" - uma interrupção brusca do som, mantendo-se o pulso ou não. No fragmento da terceira parte de Meu sabiá, de Raul Silva, do Ex. 26, a melodia aguda é interrompida no início do c. 4, sendo assumida pela grave em c. $4-5$ e voltando à aguda a partir do c. 5 neste caso mantém-se sempre o pulso. No fragmento da primeira parte de André de sapato novo, de André Victor Corrêa, no Ex. 27, a melodia aguda é interrompida no início do c. 4, sendo assumida pela grave em uma nota (Ré) em fermata no próprio c. 
4, com o pulso interrompido ${ }^{18}$, que retorna a partir da última semicolcheia do c. 4 .

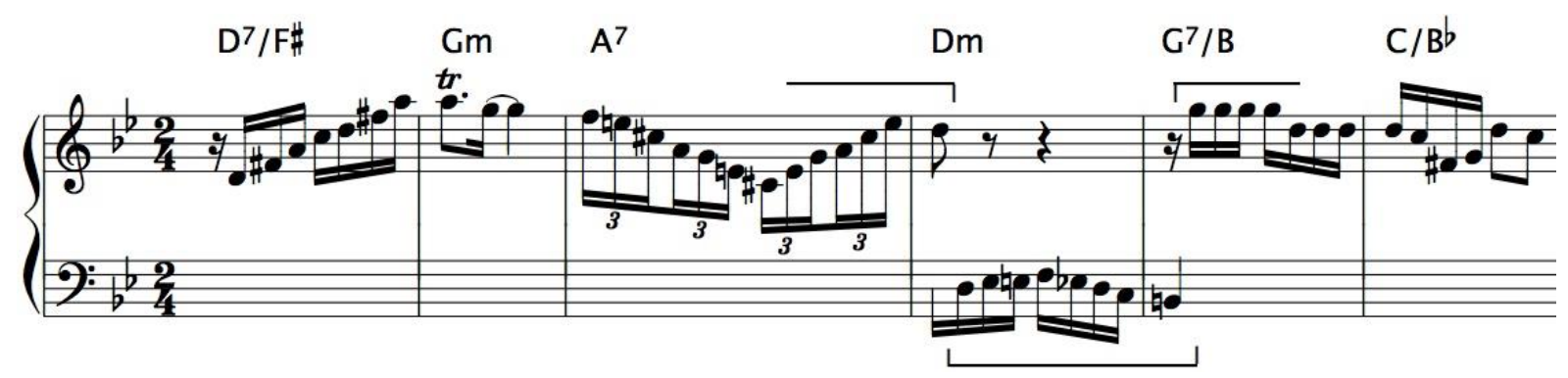

Ex. 26 - abruptio em Meu sabiá

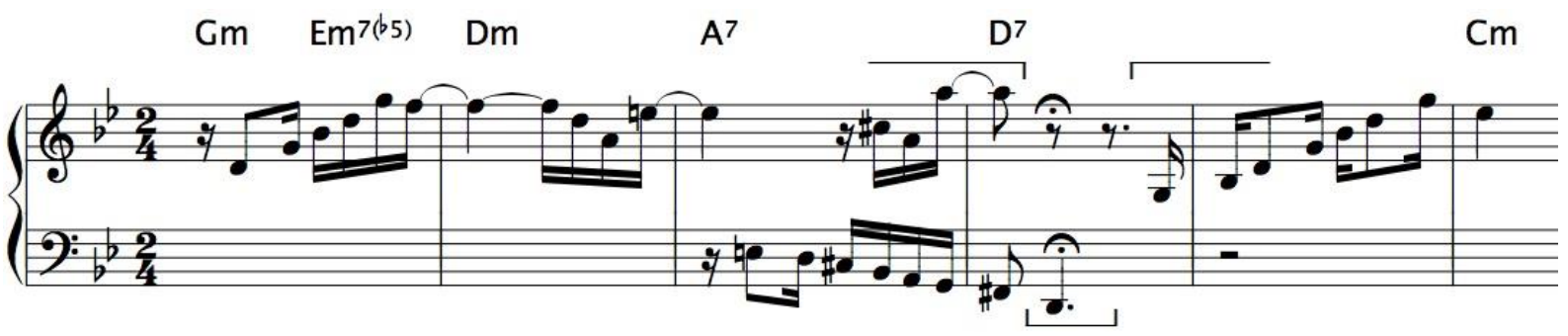

Ex. 27 - abruptio em André de sapato novo

A pausa consiste no silêncio em algumas das vozes de um fragmento, que pode ocorrer, segundo Ferrucio Civra:

1. para a respiração do cantor; 2. para variar ou suavizar um canto;_3. para evitar a sucessão imediata de acordes perfeitos; 4. para evitar a falsa relação cromática;_5. para inserir mais outra voz ou ordenar as vozes já presentes quando estão muito próximas; 6. para fazer perguntas e para responder; e_7. para evidenciar o conteúdo do texto. (CANO, 2011, p. 195)

É habitual nas práticas dos choros o jogo de perguntas e respostas entre melodias principais (como as tocadas por flautas, bandolins, cavaquinhos, clarinetes etc.) e contrapontos (como os tocados por violões de sete cordas, saxofones tenores, trombones etc.), entrecortados por breques. O início da polca-choro Ele e eu, de Pixinguinha e Benedito Lacerda, no Ex. 31, ilustra esse procedimento.

\footnotetext{
${ }_{18}$ Segundo relatos do clarinetista Abel Ferreira, em suas apresentações, o breque em fermata referia-se à parada do dançarino de gafieira (de nome André) para queixar-se das dores causadas pelo uso de seu novo sapato, ainda muito apertado em seu pé.
} 


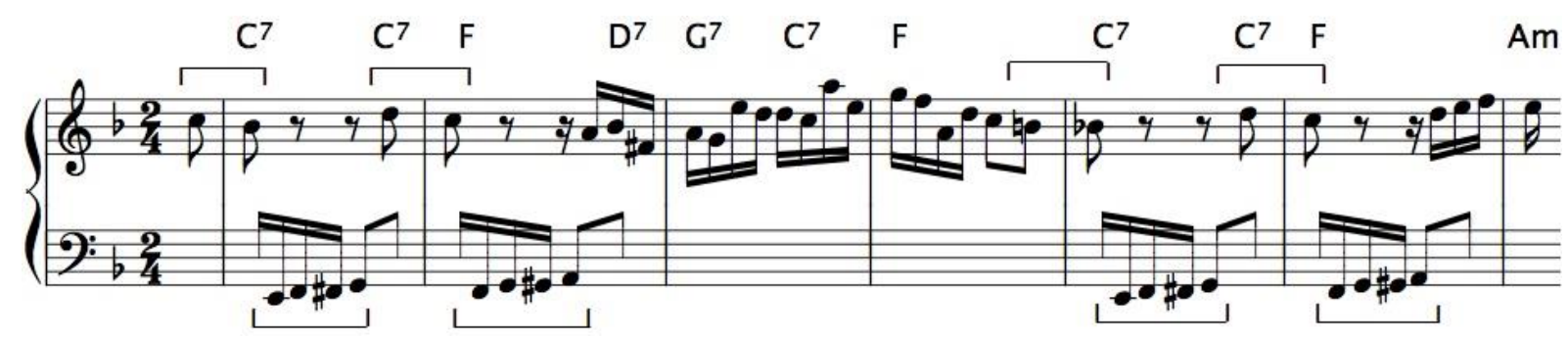

Ex. 28 - pausa em Ele e eu

A suspiratio, uma figura de "subtração" por silêncio, como a pausa, consiste em um fragmento melódico interrompido por meio de breves interrupções espalhadas ao largo deste, em forma de suspiros, como em L'Incoronazzione di Popea, de Monteverdi (CANO, 2011, p. 196). Para Kircher, é a maneira de representar suspiros de uma alma sofrida. (CANO, 2011, p. 196).

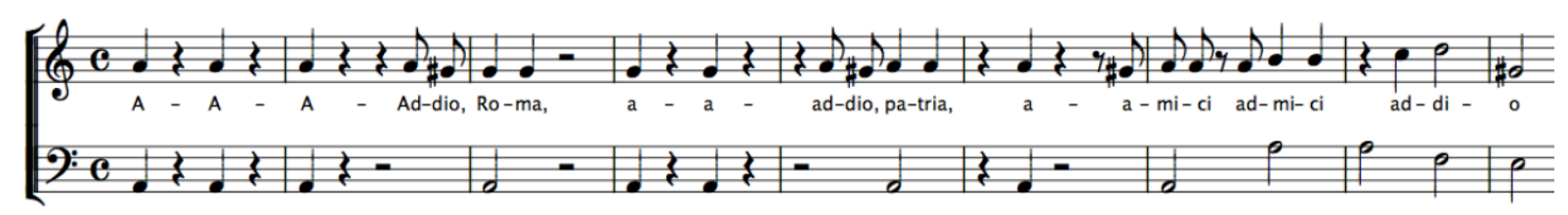

Ex. 29 - suspiratio em Claudio Monteverdi

Embora sem expressar necessariamente o mesmo sentimento, há cortes que são usuais em valsas - como os da figura "semínina-semínima cortada, seguida de pausa", no fragmento da segunda parte de Terna saudade, de Anacleto de Medeiros, nos c. 2 e 4 do Ex. 29 - e tangos brasileiros, maxixes e choros - como os da figura "colcheia pontuada-semicolcheia, seguida de pausa", no início de Dinorah, de Benedito Lacerda, do c.1 ao 5, no Ex. 30 (id., 2007, p. 124). Valsas e choros, como os citados, podem também apresentar cortes nos acompanhamentos.

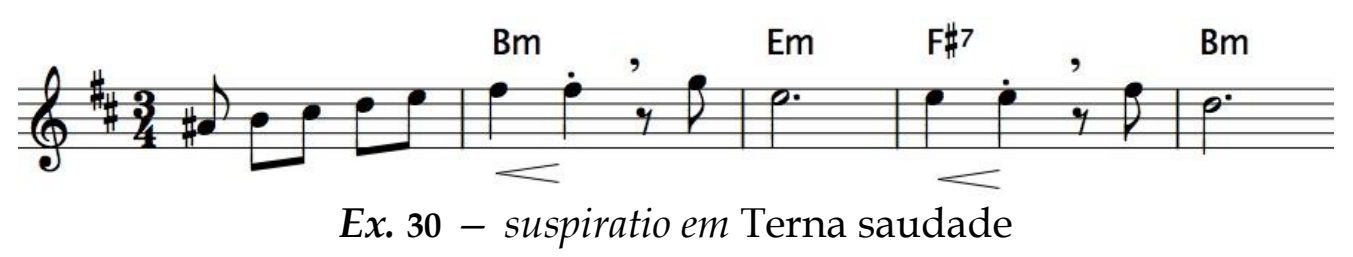




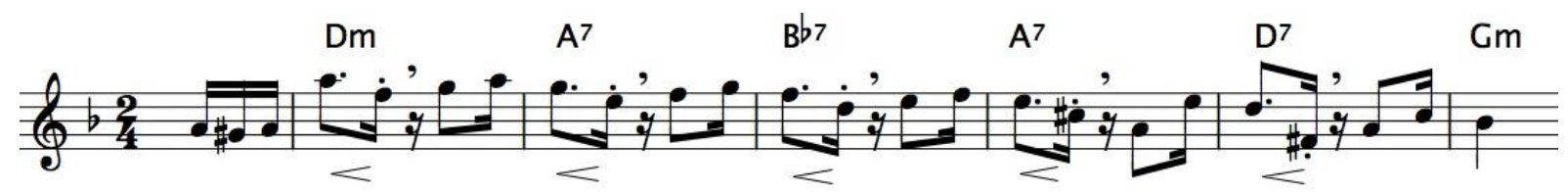

Ex. 31 - suspiratio em Dinorah

Descendente, em parte, de danças europeias contemporâneas aos períodos clássico e romântico, o choro fundamenta-se em diversos aspectos estruturais do tonalismo sedimentados a partir do barroco tardio, quando a retórica ainda fazia parte da vida cultural e o modelo para o discurso sonoro, vocal ou instrumental, era a fala. Lançando mão de diferenças estilísticas, esses períodos foram, de muitas maneiras, em busca de procedimentos musicais para expressar afetos - expansões monomotívicas, fluxos melódicos contínuos, simetrias fraseológicas, elementos contrastantes, construções programáticas (muitas vezes, sob estímulos literários) etc. Todos eles recorreram, como substrato musical, às danças populares e folclóricas como Bach, nas sonatas e suítes, Mozart, nos rondós e minuetos, ou Chopin, nas mazurcas e polonaises. Ao analisar uma música fundamentada (em parte) em danças europeias e aspectos semelhantes aos expostos - como é o caso do choro - , seria possível realizarmos associações com as sistematizações construtivas da música poética? Muitos conceitos retóricos seguem presentes em nosso dia-a-dia - ora na organização do que falamos ou escrevemos, ora no uso expressivo das palavras e das figuras de linguagem que nos são familiares. Procedimentos similares não estariam há algum tempo refletidos na música (popular) que temos composto, tocado ou ouvido?

Este artigo buscou apresentar uma alternativa para a análise da percepção de sentidos no repertório dos chorões, ao realizar paralelos com a retórica musical. $\mathrm{Na}$ maioria das vezes formado por peças instrumentais, o gênero brasileiro tem recorrido a padrões musicais (melódicos, rítmicos e harmônicos) de sua memória coletiva para apoiar a construção de seus discursos.

Ao usar o modelo das danças e dos rondós, o choro (e outros gêneros relacionados) tem, por exemplo, nas "figuras de repetição" entre seções, períodos e motivos ou padrões de acompanhamento uma de suas marcas. Motivos melódicos como os exemplificados - repetem-se de maneiras diferentes, evitando-se possíveis 
situações de monotonia. Por serem dispositivos que facilitam a memorização, é bastante comum o uso de repetições e sequências em músicas populares.

"Figuras de dissonância", ornamentos e inflexões melódicas (como as apojaturas, bordaduras e cambiatas utilizadas a partir do período barroco) constituem-se em elementos importantes no embelezamento do discurso musical dos choros. ${ }^{19}$ Contornos melódicos (sinuosos, recortados ou descendentes precedidos de saltos) e flexibilizações rítmicas podem apresentar significados próprios ao descreverem, em muitos matizes, movimentos e sensações - indo além da dicotomia alegre/triste, simplesmente. Até porque na música, em geral, como lembra um famoso maestro argentino, a alegria e a tristeza existem simultaneamente e, por isso, permitem que se tenha o sentimento de harmonia. (BARENBOIM, 2009, p. 25).

Mesmo que estejam longe de obedecer a uma "lógica cartesiana", os títulos das peças instrumentais do repertório chorístico, se vistos como "figuras de descrição", podem ser lidos como pistas para a compreensão de seus significados. ${ }^{20}$ Há exemplos de ações (como Escorregando, Beliscando, Chorando baixinho, Descendo a serra etc.), citações de estilos musicais ou épocas (como Maxixe do Galo, Chorinho pra ele, No tempo da vovó etc.), homenagens a pessoas ou lugares (como Sarau para Radamés, Evocação a Jacob, Rio antigo etc.), entre outras motivações ou inspirações.

Mas algo estrutural no discurso do gênero poderia merecer ainda um estudo "retórico" à parte: o ritmo. Não seriam certos padrões rítmicos, nos fraseados ou acompanhamentos, indicativos de diferentes discursos e construções musicais, sejam elas de origens europeias ou africanas? Esta me parece uma questão relevante no sentido de dar seguimento a esta pesquisa.

\footnotetext{
19 O músico Carlos Almada (2006, p. 34) diz que, "descontando, as particularidades rítmicas, estilísticas e texturais de cada caso", encontrou nas seis Suites Francesas, de J. S. Bach, a ocorrência de inúmeras das figuras usadas no repertório de choros que pesquisou.

${ }^{20}$ Siqueira (1969, p. 114) contrapõe uma curiosa análise retórico-musical aos títulos que Callado atribuía às suas polcas, que "muitas vezes eram improvisadas com intenção programática. Mas em razão dos andamentos, sempre vigorosos - pois raramente atendia ao sentimentalismo, suas mensagens sonoras, ora demonstravam alegria e volúpia, (...) ora queixumes e incertezas, procurando a sugestão direta, nos saltos quase impossíveis."
} 


\section{Referências}

ALMADA, Carlos. A estrutura do choro: com aplicações na improvisação e no arranjo. Rio de Janeiro: Da Fonseca, 2006.

ANDRADE, Mário de. Pequena história da música. São Paulo: Livraria Martins, 1942.

ARAGÃO, Pedro. O baú do Animal: Alexandre Gonçalves Pinto e o choro. Rio de Janeiro: Livraria e Edições Folha Seca, 2013.

BARENBOIM, Daniel. A música desperta o tempo. São Paulo: Martins Editora, 2009.

BARTEL, Dietrich. Musica poetica: musical-rethorical figures in German baroque music. U.S.A: University of Nebraska Press, 1997.

BUELOW, George J. Rhetoric and music. In: The New Grove Dictionary of Music And Musicians. London: Macmillan Publishers Limited, 1980. Vol. 15; p. 793-803.

CANO, Rúben López. Música y retórica en el barroco. Barcelona, Espanha: Amalgama Edicions, 2011.

CARRASQUEIRA, Maria José. O melhor de Pixinguinha: melodias e cifras. Rio de Janeiro: Irmãos Vitale, 1997.

CAZES, Henrique. Choro: do quintal ao Municipal. São Paulo: Editora 34, 2010.

CURY, Thiago, MACHADO, Cacá. Todo Nazareth: obras completas: F-O: tangos, vol. 2. São Paulo: Água Forte Edições Musicais, 2011.

DESCARTES, René. As paixões da alma. In: Os pensadores: Descartes. São Paulo: Nova Cultural, 1999.

HARNONCOURT, Nikolaus. O discurso dos sons: caminhos para uma nova compreensão musical. Rio de Janeiro: Jorge Zahar, 1998.

KIEFER, Bruno. A modinha e o lundu: duas raízes da música popular brasileira. Porto Alegre: Editora Movimento, 1986.

KOOGAN, Abrahão; HOUAISS, Antônio. Enciclopédia e dicionário ilustrado. Rio de Janeiro: Editora Guanabara Koogan,1993

LEMOS, Maya Suemi. Apostila da disciplina História da música e musicologia: tópicos sobre a música medieval, renascentista e barroca. Rio de Janeiro: UNIRIO, 2015. 
Retórica e elaboração musical no período barroco: condições e problemas no uso das categorias da retórica no discurso crítico. Per Musi, Belo Horizonte, n. 17, 2008, p.48-53.

PIEDADE. Acácio Tadeu. Expressão e sentido na música brasileira: retórica e análise musical. Revista eletrônica de musicologia. Volume XI, set. 2007.

PIEDADE, Acácio Tadeu; FALQUEIRO, Allan Medeiros. A retórica musical da MPB: uma análise de duas canções brasileiras. In: XVII Congresso da ANPPOM. Anais do Congresso, 2007.

PINTO, Alexandre Gonçalves. O choro: reminiscências dos chorões antigos. Rio de Janeiro: Typ. Glória, 1936.

QUANTZ, Johann Joachim. On playing the flute. Tradução Edward R. Reilly. 2nd ed. Boston, USA: Northeastern University Press, 2001.

RATNER, Leonard G. Classic music: expression, form and style. USA: Schirmer Books, 1980.

REBOUL, Oliver. Introdução à retórica. São Paulo: Martins Fontes, 2004.

ROSEN, Charles. The classical style: Haydn, Mozart, Beethoven. New York, USA: W. W. Norton \& Company, 1997.

SANDRONI, Carlos. Feitiço decente: transformações do samba no Rio de Janeiro (1917-1933). Rio de Janeiro: Jorge Zahar, 2012.

SEVERIANO, Jairo. Uma História da Música Popular Brasileira: das origens à modernidade. São Paulo: Editora 34, 2009.

SIQUEIRA, Baptista. Três vultos históricos da música brasileira. Rio de Janeiro: Biblioteca Nacional, 1969.

SODRÉ, Muniz. Samba, o dono do corpo. Rio de Janeiro: Mauad, 2007.

TAGG, Phillip. Melody and accompaniment. Encyclopedia of Popular Music of the World (EPMOW), p. 1-24. Disponível em

<http://tagg.org/articles/xpdfs/melodaccUS.pdf> Acesso em: 8 mai. 2015.

TINHORÃO, José Ramos. Pequena História da Música Popular: da Modinha à Lambada. São Paulo: Art Editora, 1991.

ULHÔA, Martha Tupinambá de. Entrevista com Philip Tagg. Debates: Cadernos do Programa de Pós-graduação em Música, Rio de Janeiro, n. 3, março, p. 81-96, 1999. 